Int. J. Dev. Biol. 49: 85-103 (2005)

doi: $10.1387 / \mathrm{ijdb} .041952 \mathrm{nl}$

Special Review

\title{
The Nogent Institute - 50 Years of Embryology
}

\author{
NICOLE M. LE DOUARIN* \\ Laboratoire d'Embryologie Cellulaire et Moléculaire, CNRS UMR \\ 7128, Nogent-sur-Marne, France
}

\section{The Institut d'Embryologie in Nogent-sur-Marne: origin and intellectual heritage}

The Nogent estate became a laboratory dedicated to the study of embryology in 1955 when Etienne Wolff was elected as a Professor at the Collège de France where the chair of «Embryologie Expérimentale» was created for him (see Dieterlen-Lièvre, 1990). The laboratory he developed, affiliated with both the Collège de France and the CNRS, was situated in two distinct locations, one in the historical building, Place Marcelin Berthelot in Paris and the other in a mansion donated to the Collège de France in the 1940 ies by the late Pr. d'Arsonval. This wealthy family house sat in a park planted with magnificent trees and ornamental bushes, bordering the residential suburban city of Nogent-sur-Marne in the «Bois de Vincennes".

Before being appointed to the Collège, Etienne Wolff held a Professorship at the University of Strasbourg where, back from a four year stay in a German prisoner camp, he had developed an already large laboratory supported by the CNRS. The Nogent venture was part of a significant national effort in the $1950^{\text {ies }}$ to recreate a national corpus of research, on the ruins left by the war.

Given the choice between the CNRS campus in Gif-sur-Yvette and the Nogent site, Etienne Wolff chose Nogent and had it completely renovated, one floor becoming his own apartment, the rest being transformed into a modern laboratory. A large part of the building was already a laboratory in d'Arsonval's time.

Etienne Wolff was already famous for his finding that the recently discovered oestrogens were able to influence the sexual development of the chicken embryo. He showed that these hormones transformed genetically male birds, which developed

\footnotetext{
${ }^{1}$ At that time and up to the 1970 ies, the grade of Docteur ès Sciences d'Etat was delivered upon defence of a main and a secondary thesis.
}

an ovarian cortex and retained Müllerian ducts. This first demonstration of a hormonal effect in the developing embryo opened a large research avenue brilliantly developed in France, apart from Etienne Wolff's own laboratory, by Alfred Jost in mammals and Louis Gallien in amphibians. Wolff's experiments were carried out just before the second world war (Wolff, 1936a,b) and were reported in his secondary thesis ${ }^{1}$. This piece of work was experimental rather than an analytical assay as was usual, an exceptional fact and a testimony to the intellectual dynamism and enthusiasm for biology displayed by this young man whose initial university education was in Philosophy.

Etienne Wolff's main thesis, published in 1936 in the Archives d'Anatomie, d'Histologie et d'Embryologie is a monumental study about Teratology. How do the «monsters», which sprinkle from time to time the human or animal descent, emerge? Some mechanism must go astray during development. The rational sustaining this work was to try and reproduce the morphological abnormalities in the hope of finding cues as to how and why they appear and more interestingly of acquiring information about the normal embryological course. This was long before the time when any genes responsible for developmental malformations were identified. Wolff's thesis, a masterpiece, still provides accurate information to avian embryologists.

In the two laboratories he created as a Collège de France Professor, the number of investigators funded either by the CNRS or the Collège was already significant in the lates $1950^{\text {ies }}$. Each was in charge of his own project, team work being rare in this time,

\footnotetext{
Abbreviations used in this paper: AIP, anterior intestinal portal; AP, anteriorposterior; CNS, central nervous system; ENS, enteric nervous system; NC, neural crest; NCC, neural crest cell; PNS, peripheral nervous system; $Q / C$, quail/chick; RNP, nucleolar ribonucleoproteins.
} 
so that the problems tackled were very diverse, ranging from regeneration in planarians and neural induction in amphibians to teratological effects of various drugs like for instance thalidomide. The persistent interest of Etienne Wolff for the effects of ionising radiations originated the works of Georges Le Douarin on the effects of X-rays on cardiac development (Le Douarin, 1964) and of Jean-Michel Kirrmann (Kirrmann, 1962). However the two major trends concerned, firstly, sexual differentiation which was directly related to Wolff's previous findings, namely the effects of steroid hormones on the developing genital tract and, secondly, tissue interactions occurring during organ development. Wolff's laboratory also contributed significantly to the studies active in the late $50^{\text {ies }}$ and in the $60^{\text {ies }}$ on limb (Madeleine Kieny) and - to a lesser extent - kidney development (Madeleine Gumpel, Yvon Croisille, Claude Martin). The work of Philippe Sengel on the interactions between dermis and epidermis in feather growth and differentiation in chick embryo was fully original and remains a classic (Sengel, 1976). Danielle Dhouailly in Grenoble University, one of Sengel's former students, pursues this line of research and produces internationally recognized findings (See for example Dhouailly et al., 2004; Olivera Martínez et al., 2004; Fliniaux et al., 2004 and a collection of other papers published recently in the Int. J. Dev. Biol. Special Issue [2004, Vol. 48, Nos. 2/3] entitled "Skin Development", edited by Danielle Dhouailly herself).

One of the trends in physiology and developmental biology in the $1960^{\text {ies }}$ was to dissect processes, previously described in the animal, in simplified systems, that is, on tissues isolated and grown in vitro in organotypic cultures, where they maintain their tridimensional structure and in which the two interacting players can be separated by filters with adequate pores, allowing or not cell traffic and passage of molecules with various sizes. Morphogenetic interactions between the initial components of organ rudiments were undisputably demonstrated by these means in other laboratories, for instance in the case of the kidney (Clifford Grobstein and Lauri Saxen), the pancreas (William Rutter) or the mammary gland (Klaus Kratochvil).

With one of his most skilfull collaborators, Katy Haffen, Etienne Wolff developed a culture technique with which he himself and his coworkers, among whom his spouse and colleague Emilienne Wolff, analysed the responses to steroids of various organ rudiments. This culture technique was based on the incorporation of nutriments in a semi-solid agarose gel, the tissues being placed at the interphase between air and medium. It was commonly used by researchers interested in tissue interactions during organogenesis.

\section{My early research experience}

I came to Nogent in the late $50^{\text {ies }}$ when the laboratory was at its peak. Broadly, my project concerned the digestive tract. Not much interest was directed to endoderm and its derivatives at that time and the message I received, along with some practical advice, was that I would find something worth investigating in this area. I first tried to understand how, while the embryo is composed of flat sheets of cells (the three germ layers) during the first and second days of incubation (E2), the cylindrical gut could be generated as well as its specialized digestive organs and appendages. I systematically labelled various endodermal areas with carbon particles and followed their relative movements as the gut became organized. Also using X-rays to selectively destroy definite regions of the embryo, I gained insight into the localization of the territories that yield the different parts of the bowel and appended glands and on their relative movements during organogenesis. This led to the construction of an endo-mesodermal fate map, a basis for my further studies.

I immediately became interested in liver development and found that, early in ontogeny, a small number of endodermal cells located in the anterior intestinal portal (AIP) are committed to the hepatocyte developmental programme. However, to pursue this fate, they need the help of growth factor(s) provided by the hepatic mesodermal component (Le Douarin, 1964a,b). The latter however is not easily recognizable since, at the same time it individualizes from the omentum (or septum transversum), it becomes colonized by strands of epithelial cells, which immediately divide and differentiate into hepatocytes. These cells arise from the committed pre-hepatocytic endodermal area I had localized in the AIP and which undergoes a rostro-caudal migration as the pre-umbilical gut closes ventrally. I had to devise a microsurgical trick to prevent the colonisation of the hepatic mesoderm by hepatocytes in order to obtain it pure, a prerequisite to study its action on the endoderm. Interestingly, the so-called mesodermal component of the liver appeared entirely composed of cells from the endothelial lineage which line the hepatic sinusoids (Fig. 3). Thus the hepatocytes are, from the onset of liver development, closely associated with the blood stream. Interestingly, in mammals and in certain species of birds, the liver functions transiently as a hemopoietic organ.

It turned out that the commitment of the AIP endoderm to a hepatic fate results from an even more precocious interaction between mesoderm and endoderm. The endodermal hepatic territory in the AIP forms by assembly of two lateral areas which, at the head process stage, sit upon the pair of cardiogenic mesodermal territories. I could show that the pre-cardiac mesoderm signals the associated endoderm at the 5-6 somite-stage, when the two germ layers start fusing on the mid-ventral line to form the cardiac tube. In the absence of such signalling, the endoderm cannot respond to the later induction provided by the hepatic mesodermal component.

At the time of my PhD thesis (Le Douarin, 1964c), no means existed to identify the signals responsible for liver cell differentiation. These signals operate early in development and involve only a few cells, so that chemical purification methods, the only ones available then, were not appropriate. This question, like all those related to the same type of developmental processes, remained unanswered for two decades until molecular and genetic approaches became available. Unravelling the molecular mechanisms which underlie morphogenetic tissue interactions has begun only recently. The article by Anne Grapin-Botton in this issue (Grapin-Botton, 2005) is an example of the present trends of the modern research in this field.

\section{My experience as an academic}

After my PhD degree I was offered a position as Maître de Conférences (Assistant Professor) at the University of ClermontFerrand. My family stayed in Paris and I commuted to ClermontFerrand every week to give lectures. The Biology Department Chairman was Pr. Hubert Lutz, who had been the first of Etienne Wolff's research students in Strasbourg. Even though I stayed in 


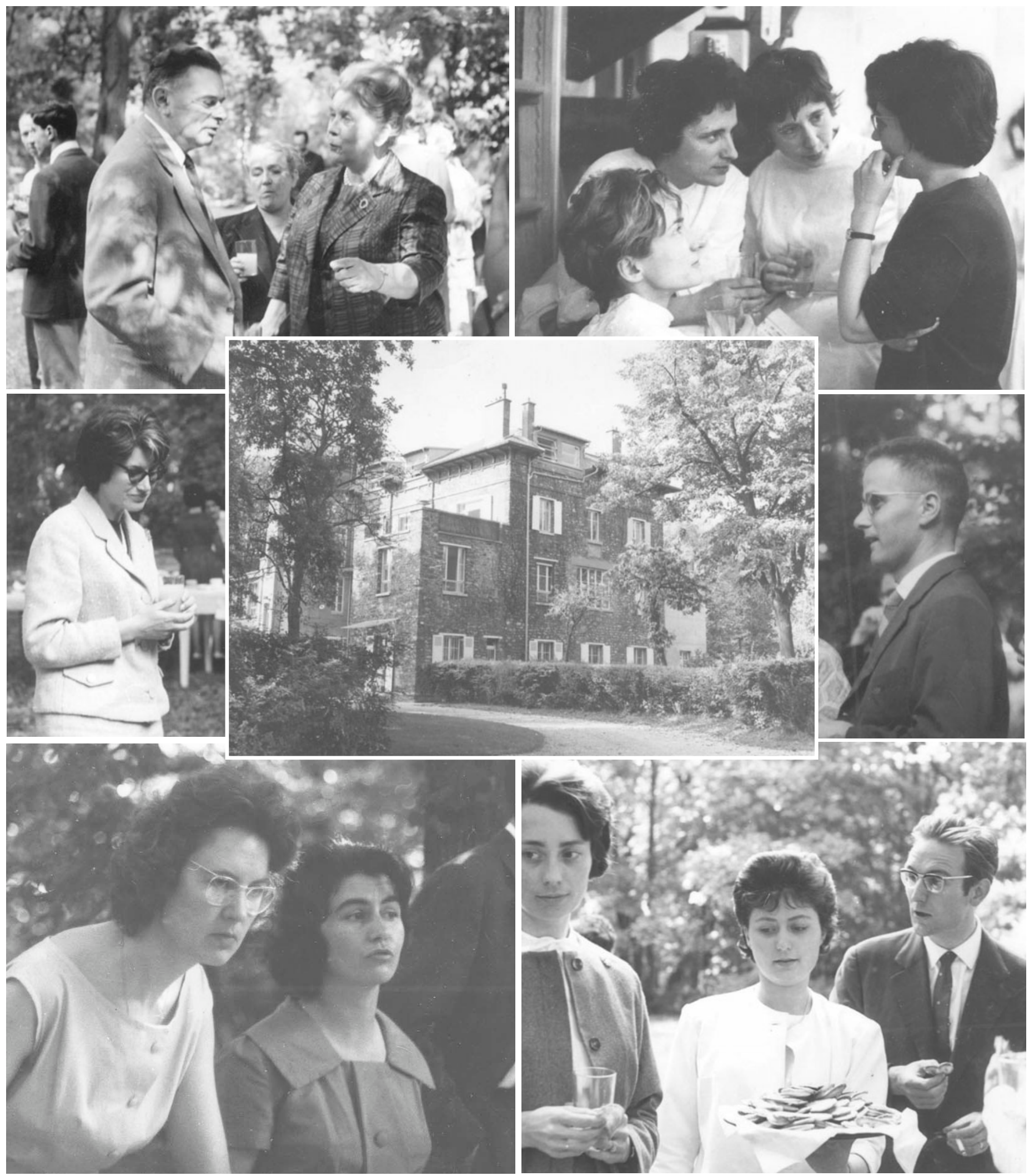

Fig. 1. Cocktail party in the garden of the Institute in the early days (June, 1961). First Row Etienne and Emilienne Wolff / Barbara Bruner, Nicole Le Douarin, Haïde Matrajt and Lea Marin. Middle Row Françoise Dieterlen / Philippe Sengel. Bottom Row Hélène Lemée and Marie Françoise Sigot / Françoise Croisille (left) and Yvon Croisille (right). 

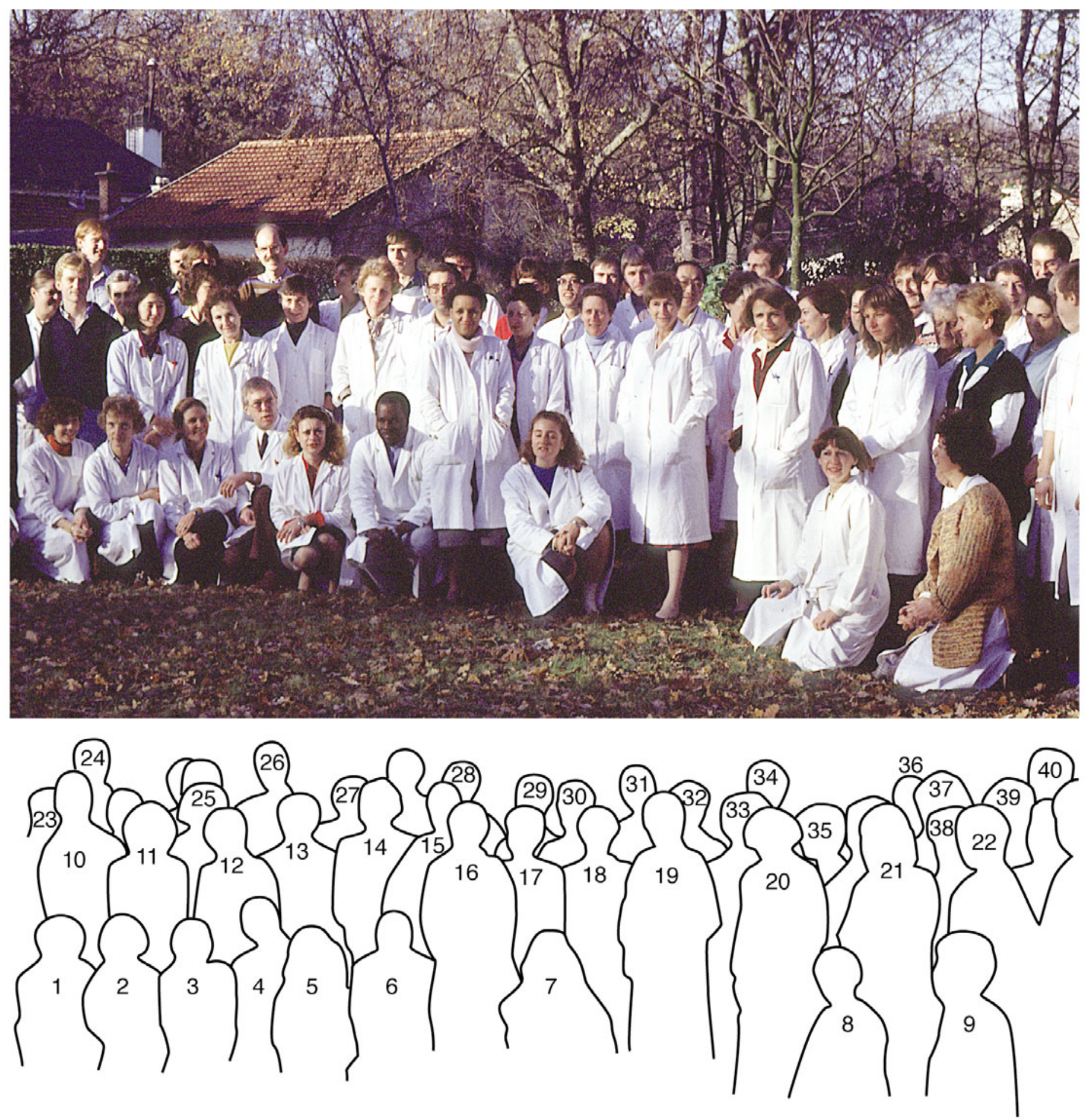

Fig. 2. Group photo in the gardens of the Nogent Institute in 1986, on the occasion of the CNRS Médaille d'Or awarded to Nicole Le Douarin. 1, Josselyne Salaün. 2, Barbara Bruner. 3, Catherine Ziller. 4, Bernard Louis. 5, Lydie Boulé. 6, Maurice Belo. 7, Patrizia CameronCurry. 8, Martine Vitrant. 9, Martine Bontoux. 10, François Guillemot. 11. Hiroko Ohki. 12, Monique Coltey. 13, Marie-Aimée Teillet. 14, Françoise Calman. 15, Miguel Cuadros. 16, Fouzia Yassine. 17, Françoise Cormier. 18, Anne Lehmann. 19, Françoise Dieterlen. 20, Nicole Le Douarin. 21, Jacqueline Leroy. 22, Claude Oudin. 23, Monique Denoyelles. 24, Gordon Tucker. 25, Catherine Corbel. 26, Beate Imhoff. 27, Marianne Barbu. 28, Yann Rantier. 29, Evelyne Bourson. 30, Pei Min Rong. 31, Gérard Gateau. 32, Zhi Gang Xue. 33, Danièle Cuminge. 34, Julian Smith. 35, Marcelle Gendreau. 36, Berthe Salzgeber. 37, Catherine Dulac. 38, Jacqueline Desveaux. 39, Suzanne Roy. 40, Thierry Jaffredo. 
Clermont-Ferrand only 2 to 3 days a week, Lutz offered me to be responsible for two students carrying out a one-year research project to graduate in biology.

I first became acquainted with the quail embryo at that time. Lutz and his wife were interested in the deleterious effects of pesticides on the development of wild birds. They used quail eggs obtained from Ernst Bösiger, a geneticist who had undertaken a vast breeding programme of this species, in order to analyze the selective advantages of hybridism. Quails seemed convenient because they lay one egg per day and become sexually mature shortly after birth. Ernst Bösiger had so many quail eggs that he proposed free quail eggs to avian embryology laboratories in place of the expensive chicken eggs that they purchased.

With the two young students I undertook an investigation of the epithelio-mesenchymal interactions critical in the development of endoderm-derived organs. We found that the AIP endoderm of the early (E2-E3) chick or quail embryo contained epithelial cells committed not only to hepatocytes but also to other cell types like the epithelial components of the pancreas, thymus and parathyroid. If grafted ectopically, the only requirement for these endodermal cells to fulfill their differentiation programme was that the associated mesenchymal substrate should be derived from the lateral plate mesoderm (i.e. splanchnopleure or somatopleure). These experiments were carried out either in quail or in chick embryo but did not involve the association of cells from the two species (Le Douarin et al., 1968).

My stay in Clermont-Ferrand lasted only a year. In October 1966 I was appointed to the University of Nantes with the opportunity to organize my own research group. Several students joined my laboratory, among whom Elisabeth Houssaint and Francine Jotereau who later both became Professors in Nantes University; Christiane Le Lièvre, Marie-Aimée Teillet, Josiane Fontaine were also among the first of a long series of co-workers; several eventually got a permanent position in the CNRS and are now Directeurs de Recherche, while others became Professors and researchers in France or in foreign countries (USA, Great Britain, Switzerland).

\section{Devising the quail/chick marker system}

A significant turn in my carrier happened during a project that continued my PhD work. I wanted to find out whether the tissue interactions observed between the hepatic mesenchyme and the AIP endoderm could take place between the two initial components when they derived from two different species. The answer to this problem seems self-evident in 2004 since we now know that the genetic networks which control the developmental pathways have been conserved during evolution, but it was not so in the late sixties. As shown in my previous work (Le Douarin, 1964a,b), when the presumptive hepatic territory is experimentally separated from the AIP by a physical barrier, the hepatic mesenchyme, which fails to be colonized by the endodermal cells, gives rise to a mini-liver lobe, consisting of a network of sinusoids and devoid of hepatocytes (Fig. 3). When this hepatic mesenchyme is cultured in association with the AIP endoderm, a lobe of hepatic tissue develops in a few days. The hepatocytes are easily recognized by their large nucleolus and their basophilic cytoplasm rich in ribosomal particles. In the experiments involving heterospecific tissue association in culture, the hepatocyte-free liver mesenchyme was removed from quail at E5 and co-cultured with the chicken AIP endoderm in the Wolff and Haffen organ culture system. The cultured tissues grew and the
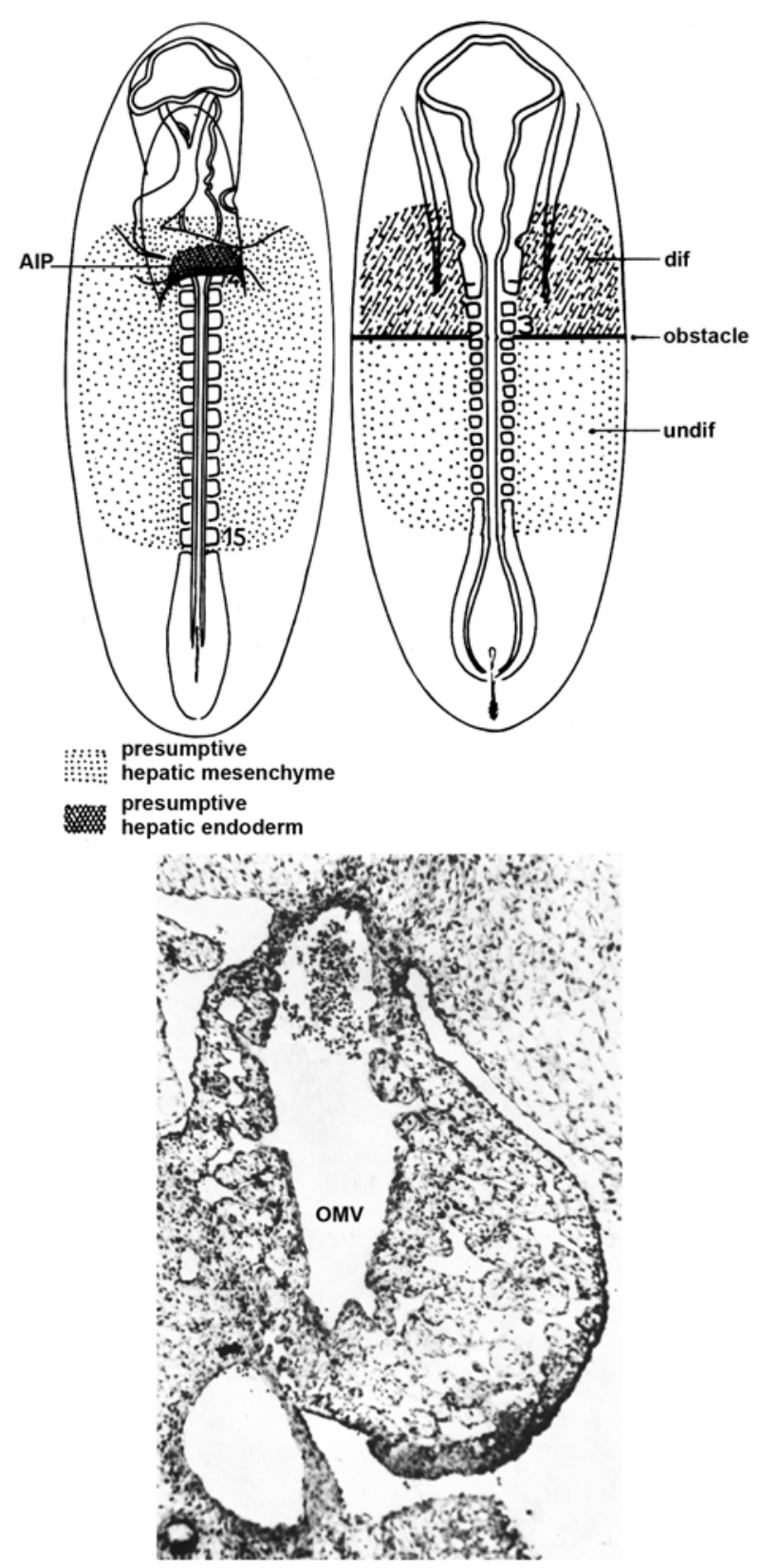

Fig. 3. Isolation of the mesenchymal component of liver tissue. (Top left) Mesodermal hepatic territory (stippled) in a 15-somite chick embryo seen from the ventral aspect. Endoderm growing from the Anterior Intestinal Portal (AIP) will invade this territory. (Top right) When a bilateral obstacle is inserted in the 13-somite embryo, ingrowth of the endoderm is prevented; the presumptive mesoderm remains emptyand differentiates into a network of sinusoids, seen below on a cross section. OMV: omphalomesenteric vein.

endodermal cells invaded the mesenchyme and acquired hepatocyte features. In quail mesenchymal cells however the nuclei seemed abnormally large. Wanting to understand this observation, I found that quail nuclei have an unusual accumulation of heterochromatin associated with the nucleolus. This was obvious in quail mesenchyme/chick endoderm combination stained with 
the DNA-specific Feulgen-Rossenbeck procedure. The heterochromatin was associated to the nucleolar ribonucleoproteins (RNP). In chicken hepatocytes, the nucleolus was Feulgen-negative (i.e., contained only a small amount of DNA as regular nucleoli do) since it was made up essentially of RNP. This 1968 observation was extended to all types of cell nuclei in the quail, though there is some variation in aspect (Le Douarin, 1973).

As mentioned above, in my thesis work I tried to decipher the morphogenetic movements that turn a flat sheet of endo-mesoderm into a cylindrical structure with expansions such as trachea, lungs, liver, pancreas and pharynx. Clearly formation of the bowel did not proceed simply by the zipping, along the ventral midline, of the endodermal sheet into a tube. Carbon particles labelling the AIP, moved rostrocaudally down to the umbilicus and the cellular material present in the AIP for a short time recruited lateral tissues during this movement. The same process was occurring in the reverse direction for the post-umbilical gut. Studies about liver development also revealed that individual and collective movements of cells are as important as differential growth to sculpt the shape of the organs and the body.

Thus, my interests were very much directed to cell migrations and it occurred to me that the unique property of quail nuclei could make an excellent label to follow specific groups of cells throughout development. Quail and chicken are closely related species of birds and, although they differ in their size at birth and their incubation period ( 21 days for the chick and 17 days for the quail), the sizes of the embryos during the first half of development are very similar. I devised the quail/chick $(\mathrm{Q} / \mathrm{C})$ chimera method on the premise that the exchange of cells between the two species should not significantly disturb embryogenesis. This was fully confirmed later on through the use of the $Q / C$ marker to study a number of developmental systems. Most often, the chicken was chosen as host and the quail as donor but, performed both ways, the experiments gave similar results.
My first thought was to apply the $\mathrm{Q} / \mathrm{C}$ chimera system to study cell migrations occurring either away from or within the neural primordium.

\section{The neural crest, an ideal model to apply the Q/C chimera system}

The neural crest (NC) is a unique structure which is characteristic of the vertebrate embryo. It was discovered in 1868 by Wilhelm $\mathrm{His}$ and the subject of active investigations during the first half of the $X X^{\text {th }}$ century, mostly on lower vertebrates (see Hörstadius, 1950 and Le Douarin, 1982, for reviews). Extirpation experiments, performed in the chicken, had yielded only a sketchy view of the $\mathrm{NC}$ contribution to vertebrate embryogenesis, because no reliable method to label pre-migration NC cells (NCC) selectively and stably, was available. $\mathrm{Q} / \mathrm{C}$ cell association provided a labelling method in the avian embryo, which is accessible to experimentation in the egg during the whole developmental period.

In the case of NCC, I followed procedures devised earlier for amphibian (cf. Hörstadius, 1950) and avian (cf. Weston, 1963) embryos. The neural tube or the neural folds were removed from the recipient embryo (e.g., chicken) before the onset of NCC migration and replaced by their counterparts from stage-matched donors (e.g., quails). Normal birds developed and could either hatch or be sacrificed any time after the operation, hence yielding a dynamic view of the pathways and timing of NCC migration.

I could show that adrenomedullary cells arose from the NC. Mostly I was fascinated by the possibilities provided by this technique to visualize the impressively broad dispersion of NCC in the developing body. With Marie-Aimée Teillet, Christiane Le Lièvre and Josiane Fontaine, we unravelled the migration of NCC from various levels of the neural axis.

Christiane Le Lièvre specialized in cephalic NC. Johnston's results in 1966, obtained with ${ }^{3} \mathrm{H}-\mathrm{TdR}$ labelling, had suggested that the contribution of the NC to the facial skeleton was much
A

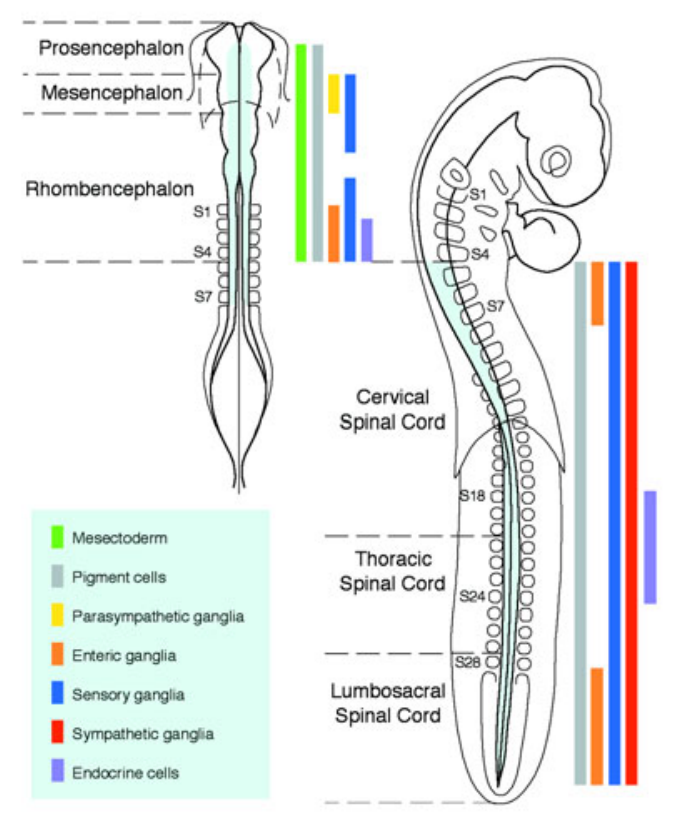

B

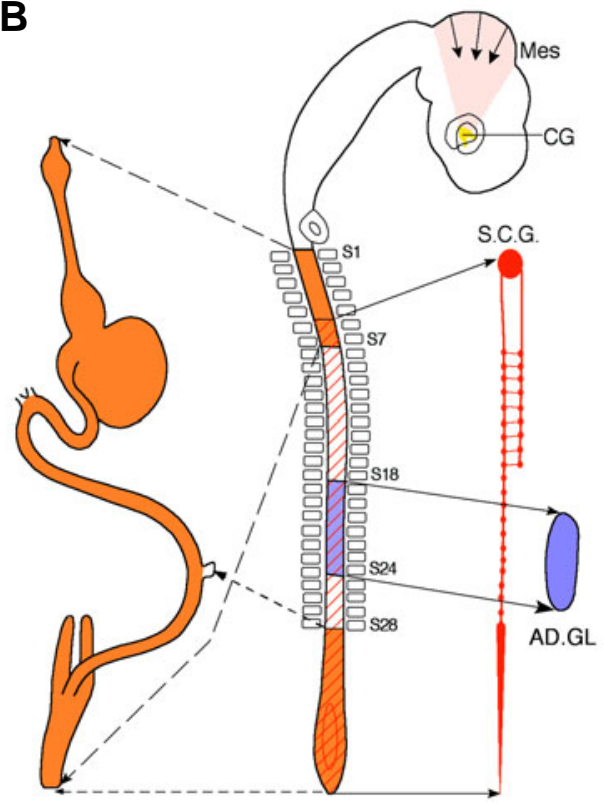

Fig. 4. Fate map of the NC. (A) The levels of origin of the main derivatives of the $N C$ are indicated along the neural axis at two developmental stages, 7and 28-somite(s) stages. $A D . G L$, adrenal gland; CG, ciliary glanglion; Mes, mesencephalon; SCG, superior cervical ganglion. (B) Fate map of the autonomic nervous system. S1-S7: the origin of most neurons and glial cells of the ENS is located between somite 1 (S1) and somite 7

(S7). A complement of cells is provided to the post-umbilical gut from the NC of the lumbo-sacral level (caudally to S28). The sympathetic ganglion chains arise from the neural tube located from S5 to its caudal end. The adrenal gland (AD.GL) originates from the NC lying between S18 and S24. 
more important than believed on the basis of extirpation experiments. Malcolm Johnston and his co-workers immediately adopted the $\mathrm{Q} / \mathrm{C}$ chimera technique and our two laboratories established that the entire facial skeleton of the avian embryo was derived from the NC (see Le Douarin, 1982, for references).

In 1975, Christiane Le Lièvre and I established the NC origin of the connective tissue associated with the striated muscles and the buccal and pharyngeal epithelium glands, including the thymus. The participation of NCC to the conotruncus of the heart was also shown in this article, a theme later developed by Margaret Kirby and her co-workers (Kirby et al., 1985). In recent years in Nogent, Heather Etchevers (Etchevers etal., 2001) demonstrated that the wall of all the blood vessels irrigating the facial tissues and the forebrain are of NC origin except for the endothelium lining the cavities, which is mesoderm-derived.

The pioneering works of embryologists during the first half of the $X X^{\text {th }}$ century had demonstrated that the NC contributes to the mandibles and other regions of the facial skeleton. We showed however that remarkably most bones of the vertebrate head are entirely formed by ectodermal cells, originating from the neural primordium. The significance of these findings in terms of cell differentiation and evolution awaited more than ten years for full recognition.

One important date in the NC story was August 1973 when Malcolm Johnston organized a symposium at the $\mathrm{NIH}$ where about twenty group leaders, whose research was relevant, were invited to present their work. The programme was divided in sessions, each bearing on one of the numerous derivatives of the NC. Data from my laboratory were contributed to each of them.

Marie-Aimée Teillet and I were pursuing our investigations on the peripheral nervous system (PNS), systematically exploring the migration pathways and fate of the cells arising from each segment (a length of about 3-5 somites at a time) of the neural tube from the rhombencephalon down to the caudal end (Le Douarin and Teillet, $1973^{2}$ ). This work, in progress in 1973, was to develop during the next ten years. The cells colonizing the gut, which yield the enteric nervous system (ENS), appeared to originate from levels of the neural axis giving rise, on one hand, to the vagus nerve (which contains the preganglionic axons of the gut innervation) and, on the other hand, to the lumbo-sacral parasympathetic columns. The truncal domain located between these two regions did not provide cells to the gut but yielded most of the sympathetic innervation and the adrenal medulla (Fig. 4).

The development of gut innervation, an extremely interesting problem, is still the subject of intensive research, namely in Pr. Mike Gershon's laboratory in Columbia University in New York. This theme has also been taken over by Dr. Alan Burns, now Professor at University College in London, who worked in Nogent as a post-doctoral fellow in 1998. Alan Burns then acquired important data about the colonisation of the post-umbilical gut, thus enlightening the etiology of a relatively common human malformation, Hirshsprung's disease (Burns and Le Douarin, 1998, 2001).

Heterotopic transpositions between these domains, using quail cells as markers, revealed a high level of plasticity in the NCC; whichever their origin along the anterior-posterior (AP) axis, the

\footnotetext{
${ }^{2}$ Weeks's citation classic by ISI in 1987.

${ }^{3}$ Germinative centers form in secondary lymphoid organs during microbial infections.
}

cells formed derivatives characteristic of the implantation level. Cells normally fated to invade the gut and differentiate into cholinergic neurons were found able to colonize the suprarenal gland and differentiate into adreno-medullary cells and viceversa. This was the first in vivo demonstration that neurotransmitter synthesis (here catecholamines or acetylcholine) was under the control of environmental cues (Le Douarin and Teillet, 1974; Le Douarin et al., 1975a). The remarkable experiments conducted at that time in Harvard Medical School on neurons of the superior cervical ganglion of newborn rats, maintained alive in vitro, also uncovered the plasticity of the neuronal phenotype in terms of neurotransmitter choice: conditioned medium from glial or cardiac muscle cell cultures was able to induce the switch from adrenergic to cholinergic functions in these neurons (e.g., Patterson and Chun, 1977).

We found at that time that differentiated PNS ganglia up to hatching (and very likely also in adults) contained undifferentiated precursors which, if removed from their «niches», exhibit differentiation potentialities very close to those of the early NCC (Schweizer et al., 1983). This problem led us to set up a fruitful and very interesting collaboration with Dr. Taube Rothman and Pr. Michael Gershon of the Department of Anatomy of Columbia University (Fontaine-Pérus et al., 1989).

We revisited the origin, previously investigated by Victor Hamburger (1961) of cephalic sensory ganglia. These are composed of a proximal ganglion in which both neurons and glial cells are derived from the NC and a distal ganglion in which the neurons originate from cephalic placodes (Ayer-Le Lièvre and Le Douarin, 1982). Exploring the fate of the cephalic NC led to the demonstration with Christiane Le Lièvre and Josiane Fontaine that the carotid body and the calcitonin-producing cells originate from the NC. This finding (Le Douarin and Le Lièvre, 1970, 1971, 1972; Le Douarin et al., 1972, 1974) was followed by a very pleasant and productive collaboration with Anthony Pearse and Julia Polak of the Hammersmith Hospital in London (Pearse et al., 1973; Polak et al., 1974).

\section{Origin, migration and homing of the hematopoietic cells}

Soon after devising the $\mathrm{Q} / \mathrm{C}$ marker system, I became interested in hematopoiesis, a subject discussed in my secondary thesis (Le Douarin, 1966). I was aware that there was no general agreement in the literature about the origin of lymphocytes that develop in the primary lymphoid organs, the thymus and the bursa of Fabricius (an organ which exists only in birds; in other vertebrates, B cells are generated in the bone marrow). $\mathrm{T}$ and $\mathrm{B}$ lymphocytes are respectively produced in these organs (hence their denomination of «primary» lymphoid organs) and seeded to the periphery, i.e. lymph nodes, tonsils, spleen and Peyer's patches, all considered as «secondary» lymphoid organs ${ }^{3}$. Although the origin of blood cells from the mesoderm was generally accepted in the late $1960^{\text {ies }}$, it was not clear whether the lymphocytes followed the same rule or not and depending on authors, either the epithelial (endodermal) or the mesenchymal stroma of the thymus and bursa were thought to give rise to small lymphocytes.

This problem appeared as easily solvable with the Q/C marker technique. With Francine Jotereau, then a young student, we undertook experiments which showed that lymphocytes are derived 


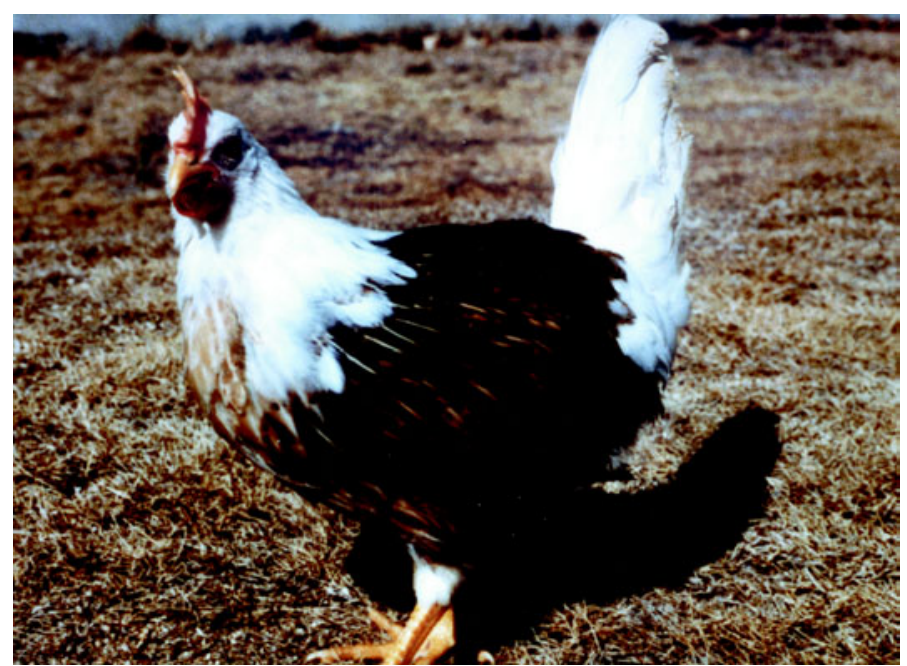

Fig. 5. Quail/chick «neural» chimera, 3 weeks after hatching. The chick host neural tube was replaced by the homologous segment from a quail embryo on day 2 of incubation at the brachial level. Melanoblasts emigrated from the graft and colonized the host's feathers at the wing level giving rise to brown pigmentation in the white Leghorn.

from hemopoietic stem cells (HSC) which invade the thymic epithelial rudiment during cyclic waves. These HSC also give rise to the dendritic cells in the medulla of the thymus. In contrast, the development of the bursa of Fabricius is characterized by a single invasion of HSC which lasts 5 to 6 days and generates B cell precursors for the entire life of the bird (Le Douarin and Jotereau, 1973; Le Douarin et al., 1975b, 1976a,b, 1977; Le Douarin, 1976, 1977; Jotereau and Le Douarin, 1982; Houssaint et al., 1976).

\section{Moving from Nantes to Nogent}

In October 1975, I moved to Paris and became the Director of the Institut d'Embryologie et de Tératologie Expérimentales when Etienne Wolff retired. Several of my coworkers and students followed me, others remained in Nantes, like Francine Jotereau with whom I continued to collaborate for a while.

The Nogent Institute offered opportunities in terms of space, technical assistance and equipment that were a hundred fold better than the rudimentary facilities I had enjoyed in Nantes. Moreover, I found there many friends, with whom I had worked 10 years before, when I was one of the members of Pr. Wolff's laboratory. I renamed it «Institut d'Embryologie Cellulaire et Moléculaire». Françoise Dieterlen, former student of Etienne Wolff, developed a dynamic group investigating the origin and traffic of hematopoietic cells in early embryogenesis of avian and mammalian embryos, a group which continues to produce original results (see Dieterlen-Lièvre, 2005 in this issue).

Several experienced investigators wanted to associate with my research and joined my group, among whom Julian Smith, a biochemist, who played an important role in our studies on the emergence of the adrenergic and cholinergic neuronal phenotypes in the neural crest and its derivatives. This analysis could be carried out after we set up appropriate culture conditions, thanks to the work and talent of Catherine Ziller (see for example, Smith etal, 1977, 1979; Ziller etal., 1979; Le Douarin etal., 1980). Pierre and Monique Coltey's technical skills were invaluable to set up new techniques to develop our programme. I recall this period with emotion. The Nantes team together with the people in Nogent were very enthusiastic about working out a new challenge.

In 1980, I reviewed the work carried out so far on the neural crest in a paper that I was invited to write for Nature (Le Douarin, 1980); and in 1982, I wrote a monograph (Le Douarin, 1982), a follow up of Sven Hörstadius's well known book, «The Neural Crest» (1950), where he summarized and analyzed the results obtained on this structure during the first half of the $X X^{\text {th }}$ century, essentially in lower vertebrate species. My own book, also called «The Neural Crest», concerned amniotes and was based on the work that we and others (among whom Malcolm Johnston and Drew Noden in the United States) had achieved using the $Q / C$ marker system.

A few years after I moved to Nogent, Jean-Paul Thiery joined us and established an independent group analyzing the expression and role of cell adhesion molecules during neural crest cell migration. Molecular techniques were later introduced in the Institute by Charles Auffray returning from a post-doctoral stage at Harvard where he had been involved in cloning genes encoding $\mathrm{MHC}$ proteins. He established his own group and started to clone genes of the chicken so-called BL complex with François Guillemot, formerly one of my most talented students. For his third cycle thesis, François Guillemot had, together with Peter Oliver, an excellent post-doctoral researcher, and Bruno Péault, demonstrated the presence of dendritic cells in the thymic medulla and their origin from blood-borne hematopoietic cells (Guillemot et al., 1984; Oliver and Le Douarin, 1984). Bruno Péault has been a very talented graduate student. He produced an antibody (MB1$\mathrm{Mab}$ ) which recognizes an antigenic determinant present in hemopoietic (except erythocytes) and endothelial cells in the quail (and not in the chick) species which was extremely useful in our further investigations. Bruno went for a long post-doctoral stay in Irving Weismann's laboratory in California (Stanford University) and came back to establish his own laboratory in France. He is now in the United States again.

I cannot mention here all post-doctoral fellows and students who passed various periods of time in the Institute, during the 25 years I had the privilege of heading it. Rather I have chosen to evoke the personalities who have been involved in the most significant scientific trends.

\section{From neurobiology to immunology: revisiting the problem of self-non self discrimination in postnatal chimeras}

The experiments performed with Marie-Aimée Teillet, Christiane Le Lièvre, Josiane Fontaine and others to explore the fate of the NCC, concerned exclusively events that took place during embryogenesis. When I gave talks however, I was often asked about the fate of the grafted quail cells and their numerous progeny in post-hatching chimeras.

When a Japanese post-doctoral fellow, Dr. Masae Kinutani, came to the laboratory in 1982, she was enthusiastic about a project that would explore the hatching ability of Q/C spinal cord chimeras and the immunological status of the graft after birth, when the host's immune system has become fully competent. Marie-Aimée Teillet obtained the first hatching of a chimera. She 
presented me with a large photograph of this bird that I keep preciously. Masae Kinutani, under the efficient teaching of MarieAimée Teillet, became one of the most skillfull «transplanter» I had around and pursued the project.

The rate of hatching was about 1 out of 10 operated embryos but, once born, the chimeras usually were healthy (Fig. 5), not for long however, as birds with a graft at the brachial level developed a paralysis of the wings and in most cases eventually died. A few animals, however, recovered complete motility and survived. The grafted segment of spinal cord appeared infiltrated with macrophages and lymphocytes and the inflammatory process further invaded the host nervous tissues. These lesions were similar to those observed in animals with induced experimental allergic encephalomyelitis (EAE) and to those occurring in human subjects affected with multiple sclerosis (MS). In addition, the chimeric birds developed neuritis in the peripheral nerves derived from the grafted spinal cord.

This pathology of the chimeras was clearly the manifestation of graft rejection but, curiously, the first signs appeared long after immunological maturity of the host. We interpreted this delay by the fact that CNS tissues have a priviledged immunological status on one hand and express no (or only little) class I and class II MHC antigens on the other. It is likely that the first immune attack on graft-derived tissues takes place in the peripheral nerves, devoid of the protective blood-brain-barrier present in the CNS. The T cells recognizing neural and glial antigens thus become activated and able to attack the CNS, in the same way as in EAE, where Tcells become activated by systemic injection of neural antigens, for instance myelin basic protein (MBP). The chimeric birds thus appeared as an experimental model for MS (Kinutani et al., 1986).

These results were at odds with the common assumption according to which antigens present during development of the immune system are later recognized as self (see Coutinho, 2005 in this issue).

To understand whether the delay observed before rejection of the graft was due to the priviledged status of the nervous tissue or whether it was related to the presence of the graft in the embryo, we undertook with Claude Martin, Maurice Belo, Catherine Corbel and a young Japanese researcher, Hiroko Ohki, a series of studies in which quail non-neural tissues, the limb bud and the bursa of Fabricius, were grafted. In both cases, the graft pursued its development in the chick embryo, reaching its species-specific size according to its own timing (Fig. 6).

Many chimeras of this type were obtained. All of them rejected the foreign wing acutely, starting at various times during the two first post-hatching weeks. The wing was totally destroyed after two months. Thus, the delay typical for neural tube grafts was not observed for non-neural tissues. This was confirmed by Maurice Belo for bursal grafts (Belo et al., 1985; Corbel et al., 1987).

At that point, it appeared relevant to investigate the immunological status of wing bud grafted between chickens of different MHC. These strains were available from the INRA laboratory of genetics at Nouzilly. The grafted wing was not rejected contrary to the outcome in $\mathrm{Q} / \mathrm{C}$ wing chimeras. However tolerance was not complete since rejection crises occurred, separated by episodes during which inflammation regressed (Corbel et al., 1990).

Inspired by a paper in Nature (Fehilly et al., 1984), I was anxious to see if manipulating the immune system of the chimera could induce permanent tolerance of the quail wing by the chicken host. On the front page of the journal was a strange animal, a sheep-goat chimera in which the tissues from the two species formed a patchwork while entertaining peaceful relationships (Fig. 7). What were the differences between the $Q / C$ wingchimeras and the sheep-goat chimeras? As mammalian chimeras result from the aggregation of two (or more) morulae, there is a chance that virtually all tissues of the animal contain cells from the two species. There is no telling the host from the recipient in this case while, in $\mathrm{Q} / \mathrm{C}$ wing, bursa or neural grafts, recipient tissues were clearly dominant over donor tissues.

I reflected that chimerism in the blood or in the thymus could be decisive for the reciprocal tolerance in sheep-goat chimeras, as thymus is the site of $T$ cell differentiation and as mouse blood chimeras produced at birth were tolerant to skin grafts of the MHC-type of the injected foreign blood cells in allogeneic combinations (Billingham et al., 1953). I knew however from a conversation with Milan Hasek that, in birds, this kind of tolerance was not induced by heterospecific blood chimerism. Consequently, we devised an experimental design in which the donor quail embryo provided not only a wing bud but also the four thymic epithelial anlagen of the $3^{\text {rd }}$ and $4^{\text {th }}$ pharyngeal pouches substituted to their counterpart in E4 chick embryos, host and donor being stage-matched.
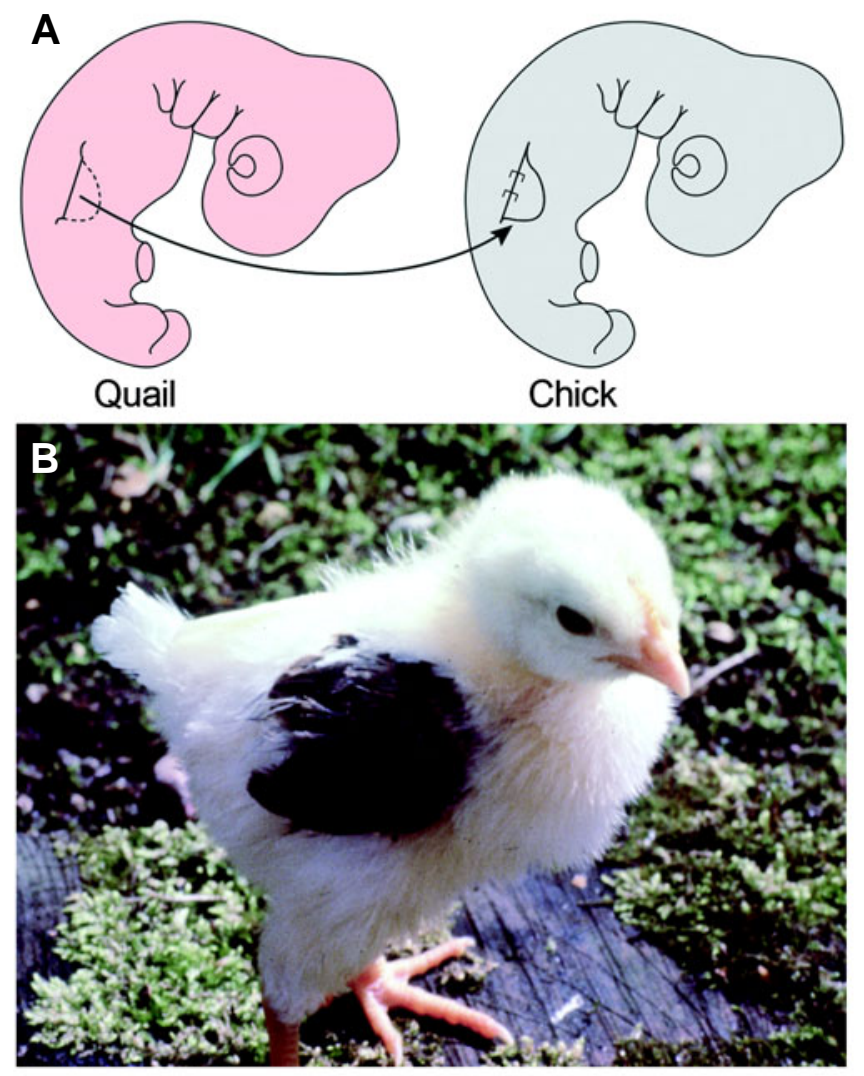

Fig. 6. Homotopic, homochronic limb bud transplantation from quail to chick embryos. (A) Design of the graft as performed on day 3-4 embryos. (B) Newly hatched chicken bearing a pigmented quail wing. The grafted wing will be acutely rejected at around 3 weeks. 


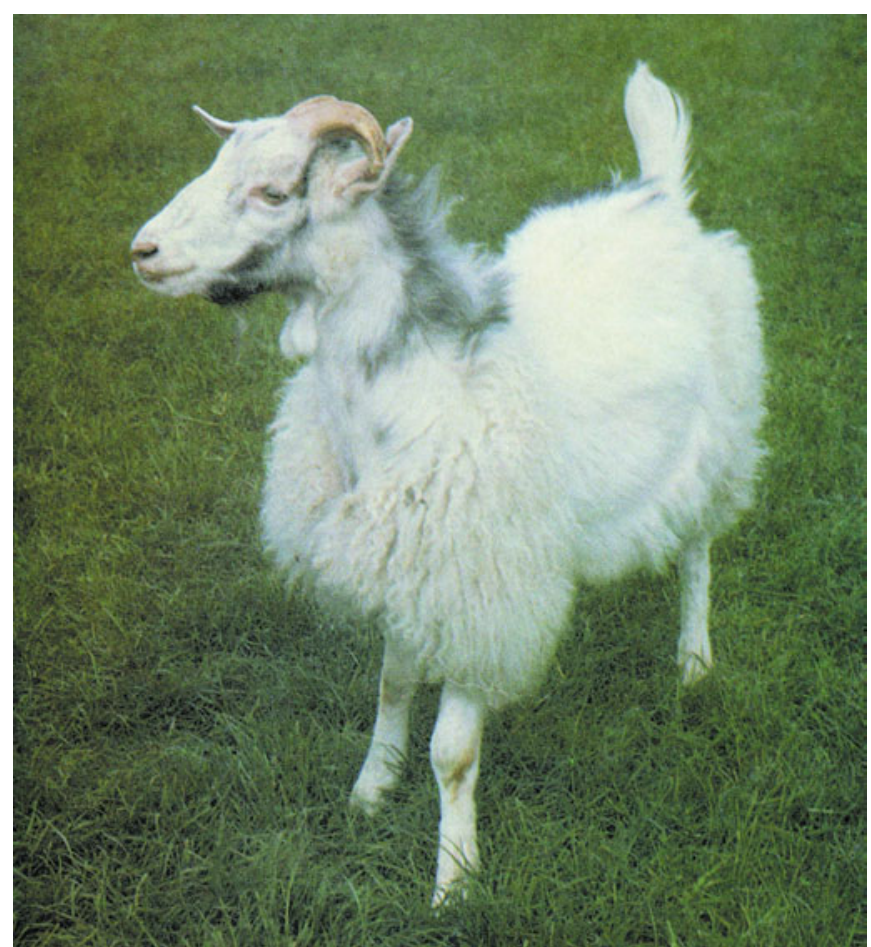

Fig. 7. A sheep-goat chimera produced by combining one 8-cell sheep embryo with three 8-cell goat embryos. It is about 1-year-old and exhibits various characters indicating its chimeric nature - a mixture of hairy and woolly areas in its coat, goat-like horns twisted like sheep horns and a mixture of sheep and goat red blood cells in the circulation (reprinted with permission from Nature, 1984, 307, cover).

The thymus operation was difficult. Claude Martin's skills in microsurgery were decisive and she taught Hiroko Ohki and Maurice Belo. As described in our paper in Science (Ohki et al., 1987), one out of 10 animals hatched. 16 birds hatched and 14 showed tolerance of the quail wing. In 3 of them slight signs of rejection appeared after about 40 days, thus much later than in $Q$ / C limb only chimeras. Two did not show tolerance (Fig. 8). The complete thymic lobes of all these double limb-thymus chimeras were studied; quail cells appeared to form the thymic epithelial stroma in all the chimeras that were tolerant. However, substitution of thymic epithelial rudiments was usually incomplete. The proximity of the branchial arch arteries made the operation difficult because haemorrhages were fatal. This technical problem made the experiment even more interesting than expected: tolerance turned out to be induced permanently if one third only of the thymic lobes was chimeric (Belo et al., 1989). This meant that chick T cells differentiating in contact with the quail thymic epithelium not only failed to aggress the quail graft but were able to «protect» the graft from the chick $T$ cells that had differentiated in the purely chick thymic lobes. When no tolerance was induced, none or very few thymic tissues were found to be chimeric.

This significant finding meant that tolerance to self did not result exclusively from the elimination of autoreactive T cells in the thymus. This process was shown to be incomplete: $T$ cells with high affinity for self components are currently found in the periphery and become harmful in autoimmune diseases. The $\mathrm{Q} / \mathrm{C}$ double chimeras showed that a mechanism at work prevented these $T$ cells from being activated in an antigen specific manner. Tolerance mediated by these cells is "active", differently from the widely accepted dogma of the default mechanism, i.e., autoreactive cell elimination in the thymus. This work was recorded in a series of papers (see for review Le Douarin et al., 1989 and Salaün et al., 2005 in this issue).

At this point we had animated discussions with immunologists, particularly with Pr. Max Cooper from the University of Birmingham in Alabama, who spent a sabbatical year with us and Pr. Antonio Coutinho who was leading an Immunobiology research unit at the Pasteur Institute. Open minded and creative, Antonio Coutinho was immediately interested by the quail/chicken chimera model and by the insights it was yielding about the mechanisms of self/ non-self recognition. We decided that we should try and reproduce these experiments in the mouse model. Josselyne Salaün in our laboratory successfully carried out this project together with Antonio Bandeira from the Pasteur group. Josselyne Salaün had been combining in vivo and in vitro studies on the mouse embryo in order to sort out the successive ontogenic steps of $\mathrm{T}$ cell differentiation (Salaün et al., 1986) and was well-prepared to tackle this problem.

Since microsurgery on the early mammalian embryos is not feasible, athymic nude mice were elected as recipients for isogeneic or allogeneic thymic epithelium grafting. Nude mice are devoid of T cells and therefore immuno-incompetent. In both combinations, $\mathrm{T}$ cell function was rescued by $\mathrm{HC}$ from the host which colonized the grafted thymic epithelium, differentiating into $T$ lymphocytes which migrated to the periphery. We were able to demonstrate that, in allogeneic combinations, the nude mice engrafted with the thymic epithelium were tolerant to both skin grafts of their own haplotype and of the thymus haplotype while rejecting third party grafts. Yves Modigliani, a graduate student in Antonio Coutinho's laboratory, showed that this tolerance was mediated by CD4 T cells. Antonio Coutinho designated it as «dominant» tolerance. These T cells, whose existence was subsequently confirmed by many other groups (see Le Douarin, et al., 1996 for a review and Coutinho, 2005 in this issue) and are called «regulatory T cells» (Treg), had to be characterized. The first important step toward their molecular characterization was due to Sakaguchi and coll. (1982) who found that such cells express CD25 in addition to CD4. A new research avenue in immunology was thus initiated, which is now expanding vigorously. At the Congress of the International Union of Immunological Societies held in Montreal on July 16 to 22, 2004 where I was invited to give a Lecture on the contribution of my laboratory to immunology, several symposia were devoted to regulatory $T$ cells and the importance they may have in transplantation medicine.

\section{Constructing chimeras to study brain development}

I had the privilege of being elected as a member of the Neuroscience Research Program (NRP). This Program was founded in 1962 by Francis O. Schmitt (1903-1995), then Professor at the MIT and chaired by him until 1974. The NRP is an informal college of scholars and research scientists whose purpose is to promote study of the brain. The NRP was just being transferred from Boston to the Rockefeller University in New York and its new chairman was Gerald Edelman. Members of the program met twice a year for a few days at the Rockefeller University in New 
York where they presented their new results or listened to invited scientists. When I presented our experiments showing that $Q / C$ neural chimeras were able to hatch and remained in a healthy condition for a long period after birth, Peter Marler, a specialist in bird ecology, then a NRP member, was in the audience. He reported these experiments to the fellows of his laboratory, one of whom, Evan Balaban, already a PhD and thinking of a post-doc, was interested by the model. He thought that it could be applied to study the problem of «nature versus nurture» in behaviour. What type of behaviour would exhibit a chimera, whose regions of the brain had been replaced by those from another bird?

When he came to Nogent, Evan Balaban chose to study the species-specific crow induced in young birds by testosterone implants. He found that crows were different in young quails and chickens. Moreover, movements of the head accompanying crowing were also different between the two species. Evan decided to look for the brain site(s) driving vocalisation and behaviours linked to crowing. Marie-Aimée Teillet took part in the project and taught Evan how to exchange specific neuroepithelial areas between E2 quail and chick embryos. At that time encephalic vesicles are not yet vascularized and fusion of graft and donor neuroepithelium takes place rapidly. These two intestigators obtained numerous $Q / C$ brain chimeras which hatched. They could determine that the crowing specific area was in the mesencephalon; a chicken with a stage-matched quail mesencephalon emitted the quail typical crowing, however simultaneous head movements were of the chicken type. When he returned to the United States and established his own laboratory, Evan was able to assign the origin of the typical head movements, accompanying the crow in the quail, to the brain stem (see Balaban, 2005 in this issue).

This work, very demanding as far as the quality and precision of the microsurgery was concerned, showed that complex behaviours like that of crowing are genetically determined in definite areas of the neural epithelium of the encephalic vesicles a long time before neuronal differentiation takes place. Thus at the early stages of neurogenesis, the neural plate is far from being a homogeneous structure with interchangeable regions. On the contrary, the neural epithelium is already the site of an underlying structuration which involves genetic and species-specific inbuilt characteristics. During neurogenesis, the various regions so defined acquire their functionality together with their differentiation in the context, however, of the connections that they establish with neighbouring structures.

\section{The epileptic chickens}

Seeing the possibility of exchanging parts of the brain between two embryos, Pr. Robert Naquet, a highly recognized specialist in epilepsy, wanted to use the avian chimera model to try and define the origin of an autosomic mendelian recessive form of epilepsy in a strain of chicken discovered in Canada by Roy Crawford in 1972. Genetic forms of epilepsy are known in humans and are characterized by seizures triggered among others by visual or auditory stimuli (e.g., intermittent light). They are considered as belonging to the sub-cortical type of epilepsy. However, what generates seizures and what brain area(s) is (are) involved in this process was not well known, though it had been proposed that the focus is located in the brain stem.
As mentioned above, the embryonic grafts of neural epithelium are rejected in interspecific chimeras one to three months after the young bird has become immunologically competent, an event which takes place about two weeks after birth. During our work on the host's immunological response to neural grafts we made an observation that opened a novel research avenue: neural grafts between MHC-different chickens were permanently tolerated. This led our group, namely Marie-Aimée Teillet, to develop a series of experiments in collaboration with Pr. Robert Naquet and Dr. Cesira Batini, a neurophysiologist from the CNRS. The disorder that affected the homozygous epileptic chickens (epi/epi) consisted in seizures of the «grand mal» type following either light or sound stimulation. By transplanting entirely or partly either the prosencephalic, mesencephalic or rhombencephalic brain vesicles, the neural pathways involved in the onset of the photic or audiogenic forms of epilepsy could be determined (see Teillet et al. 2005, in this issue). It was shown that the nucleus mesencephalicus (pars dorsalis) triggers the seizures after processing either stimulus (sound or light). The "epi» chicken mutant can thus be considered as a unique animal model for the so far poorly understood subcortical types of human epilepsy. The work on chicken epilepsy has been reviewed in Trends in Neurosciences (Batini et al., 1996; see also Teillet et al., 2005 in this issue).

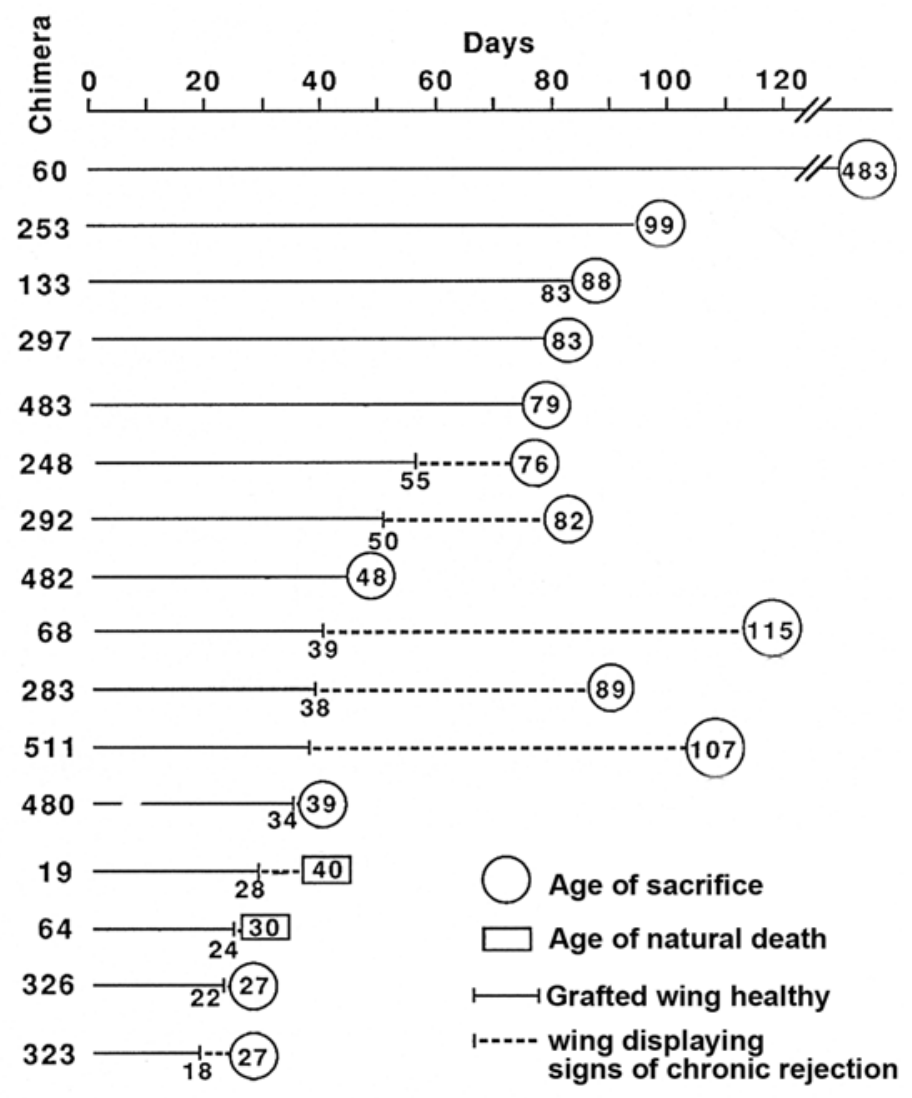

Fig. 8. Tolerance to a xenogeneic wing (quail to chick) induced by a quail thymic graft. Solid line, maintenance of the wing in a healty state after birth; dashed line, wing with signs of rejection. 


\section{Following cell migrations and morphogenetic movements during neurogenesis in the brain}

In the late $1980^{\text {ies }}$, the dominant thinking was that cell migrations in the encephalic vesicles were essentially radial; tangential migrations had not been described whereas radial migration of the neuroblasts had been clearly demonstrated by labelling the still dividing neuroblasts in the mammalian foetuses with tritiated thymidine. In 1989 two groups, using the Q/C chimera system (Balaban, Teillet and Le Douarin) or LacZ (Connie Cepko's group at Havard) carrying retroviruses as cell markers, published side by side two articles in Science (Balaban et al., 1988; Walsh and Cepko, 1988) showing that extensive tangential migrations actually occur during neurogenesis in the mammalian and avian forebrain including the cerebral hemispheres, a notion now widely accepted.

In my laboratory, these explorations were further pursued in the cerebellum by Marie-Aimée Teillet and Marc Hallonet, a graduate student. The results described in Marc's PhD thesis changed significantly the current view of the development of this part of the brain. First, it was established that, in contrast to prior belief, the cerebellar cortex did not originate entirely from the metencephalic vesicle. An important contribution from the mesencephalon was demonstrated, such that the cerebellar primordium encompasses the territory expressing the homeobox gene En2 and indeed, as later shown, agenesis follows the targetted mutation of this gene in the mouse. Grafting in avian embryos showed that the cerebellum arises from a territory equally distributed on each side of the constriction known as the midbrain-hindbrain junction.

In addition, the assumption according to which cells of the molecular layer originate from the external granular layer was found to be incorrect. We could show that these cells undergo an inward-outward migration from the ventricular epithelium, in the same way Purkinje cells do (Hallonet et al., 1990).

\section{The role of cell-cell interactions in gene regulation within the differentiating neural epithelium}

A Japanese group headed by Harukazu Nakamura, a former post-doctoral fellow of my laboratory, and the French team of Dr. Alvarado-Mallard in Paris, using the $\mathrm{Q} / \mathrm{C}$ transplantation technique, discovered that the midbrain-hindbrain junction is an important organizing center in brain development. The two groups showed that transplantation of neuroepithelial grafts from this region to the diencephalon or rhombencephalon resulted in the induction of En2 gene in the host's neighbouring neural epithelium and in the differentiation of tectal or cerebellar structures depending on the site of implantation. This led to the discovery by Dr. Salvador Martinez and coll. (Crossley et al., 1996) that the critical factor in this induction is FGF8 naturally produced in the midbrain-hindbrain junction which later on becomes the isthmus.

The fact that transcription factors expressed in the brain during development can be environmentally regulated prompted me to investigate the regulation of Hox gene expression in the rhombencephalon, a piece of work undertaken by Anne Grapin in association with Gérard Couly. When we started to investigate the problem of gene regulation in the hindbrain, the general assumption was that the expression of Hox genes in various levels of the brain was cell-autonomous and nothing was known about the upstream regulation of these genes. By performing a series of heterotopic transplantations of rhombomeres at the early stages of neurulation between quail and chick embryos, we have shown that in fact Hox gene expression at the various levels of the rhombencephalon obeys extrinsic cues and is regulated by signals transmitted through the neural epithelium itself and the paraxial mesoderm. Retinoic acid acts on this process by «posteriorizing» the anterior levels of the brain through Hox gene induction (Grapin-Botton et al., 1995).

Our experiments have also revealed that the potentiality to express Hox genes extends up to the prosencephalon. Indeed, when transplanted posteriorly, prosencephalic neuroepithelium was induced to express Hox genes corresponding to the position of the transplant along the neuraxis. Thus in normal development either the inductive signal is not present in the prosencephalic and mesencephalic vesicles or it is inhibited by antagonistic cues. Several experimental results point to the distribution of this signal as a postero-anteriorly decreasing gradient, a notion compatible with the hypothesis that retinoic acid could be involved in mediating Hox gene induction.

Transposition of rhombomeres along the neural axis does not modify Hox gene expression in transplants grafted more rostrally than their normal position. In contrast, caudal transposition results in «posteriorisation» of the neuroepithelium as far as expression of Hox genes is concerned, thus illustrating in vertebrates the "posterior dominance» demonstrated in insects. When rhombomeres $5 / 6$ were transposed to the level or rhombomeres $7 / 8$, this change in the Hox -code was followed by a homeotic transformation of the transplant phenotype. The transplant differentiated neural structures corresponding to its new AP position.

These experiments thus indicated that regulation of the Hox code at each AP level of the neural axis depends upon positional cues and showed the crucial role of Hox genes in neural specification at the rhombencephalic level.

\section{The neural crest and the vertebrate head}

An important event in the development of our work on the vertebrate head was the arrival of Gérard Couly in the laboratory in 1981. At that time he was a young pediatric maxillo-facial surgeon at the Hôpital des Enfants Malades in Paris. He was interested in the role of the NC in head development. Clearly, the results that we had just published about facial bones originating from the NC were different from the text book knowledge he had been taught as a medical student. This was the beginning of a long, still ongoing, collaboration. Dr. Couly has, over the years, managed to come to Nogent regularly every Thursday. He spends his day operating embryos at early stages (from 1 to 6 -somite stage) creating very specific chimeras to explore how the NCC construct such complex structures as the facial bones and cartilages. It has been a pleasure and a great excitement to work with Gérard Couly, interpreting cytological sections of chimeras or in situ hybridization with various nucleic acid probes or looking at the skeleton developed after microsurgery.

Several young students have contributed to this work, Anne Grapin, Heather Etchevers and more recently Sophie Creuzet a post-doctoral researcher. I wish also to acknowledge the participation of Pierre Coltey and Christine Vincent. For many 
years, he played a critical role in the progression of the results owing to the perfection of their technical work.

In vertebrates, the mesoderm gives rise to the so-called mesenchyme from which a number of different tissues differentiate: connective, adipose, cartilaginous tissues and bones. Our studies disclosed an original status for the vertebrate head, showing that contribution of the mesoderm to the skull is limited to the occipital region and, partly, to the otic and orbital capsules. The part of the skull which covers the cerebral hemispheres (frontal, parietal and squamosal bones), together with all the facial structures, originate from the NC (see Couly et al., 1993; Le Lièvre, 1974).

The mesoderm yields the striated myocytes of the facial and masticatory muscles and the endothelium lining the blood vessel lumen, while most of the mesenchyme of the head originates from the ectoderm via the NC. This constitutes a unique characteristic of the vertebrate head, which differs in this respect from the rest of the body. In the forebrain, the NC gives rise to the meninges, whereas, in the rest of the nervous system, the meninges have a mesodermal origin.

Gans and Northcutt (1983) put forward the concept of a «New Head» based largely on the conclusions that we reached in the seventies. According to these authors and on account of the NC contribution to the head shown by embryological studies, the emergence of this structure was essential for the evolutionary transition from chordates to vertebrates. Our more recent findings (see Le Douarin and Kalcheim, 1999), which significantly renewed current views on the embryology of the vertebrate head, further substantiate this important notion.

\section{Reinterpreting the development of the forebrain and the head in higher forms of vertebrates}

By following the development of the early neural primordium (the anterior neural plate), we have shown that, in its original configuration in jawless vertebrates (hagfish and lampreys), the anteriormost part of the brain corresponds to the diencephalon (thalamus, hypothalamus and pituitary gland) with only a modest development of the telencephalon dorsally. The diencephalon corresponds to the anterior end of the notocord, a vertebrate organising center that plays an important morphogenetic role at different steps of body plan patterning.

Olivier Pourquié in his post-doctoral work demonstrated that the differentiation of the paraxial mesoderm (cephalic and somitic) into cartilage and bone depends upon a signal arising from the notocord (Pourquié et al., 1993), later identified as the secreted molecule sonic-hedgehog $(\mathrm{SHH})$. The notocord present up to the mesencephalon-diencephalon junction thus accounts for the formation of the vertebral column and the occipital region of the skull. The evolution of the vertebrate phylum is characterized by the development of the cerebral hemispheres peaking in primates and humans. We focused our attention on the early developmental steps of the cerebral hemispheres and showed that the cerebral hemispheres arise from the anterior and lateral areas of the neural plate. After fusion of the neural folds and formation of the encephalic vesicles, these lateral areas are the site of intensive growth, so that they develop rostrally beyond the tip of the notocord and of the adenohypophysis. The latter becomes «burried» inside the stomodeal cavity while maintaining its close relationships with the floor of the diencephalon (to become the hypothalamus). Due to the absence of notocord and mesoderm at the telencephalic level, no skeleton could develop from mesoderm to cover the «new brain» that appeared and enlarged during the course of evolution. This new brain was covered by cells of NC origin which formed the forebrain meninges and the skull (frontal and parietal bones). Thus, co-evolution of the anterior brain and of the NC was critical for the development of higher cognitive functions in the most recent forms of vertebrates. Notably this considerable development of the forebrain has been accompanied by the emergence of sense organs, the eyes that originate from the diencephalon and the smell organs whose precursors cells we have localized in the anterior neural fold. The fate map of the neural plate that we published in 1987 (Couly and Le Douarin, 1987) has served as a reference for many investigations on the forebrain in mammals, birds, as well as Xenopus, by other groups. Acquisition of higher brain functions in vertebrates was matched by a change in life style as compared to the filter-feeder ancestors, the Cephalochordates. Vertebrates became able to seek their food and later even became predators. Their facial skeleton, which is entirely derived from the NC (see Le Douarin, 1982), involves the first organ of predation, the jaw, which is already well developed in some teleost fishes. Evolution of the vertebrate head is therefore characterized by an increased participation of ectoderm via the neural primordium. The latter not only generates the brain, but also the NC which is critical to construct the face and yields a large part of the heart and of the head vasculature. In conclusion, embryological analysis of neural crest ontogeny has shed new light on the evolution of the vertebrate phylum.

\section{Genetic control of head skeleton development from the neural crest}

Among a number of genes expressed during the development of head and face, Hox genes have attracted much attention. The anteriormost level of expression of Hox genes corresponds to the limit between two rhombomeres $(r)$ and concerns the first four paralogous groups. No Hox gene expression is observed anteriorly to the r1-r2 limit. This means that the cells which migrate to the facial primordium and construct the facial skeleton are Hox negative, whereas those forming most of the hyoid cartilage and the so-called «cardiac NC», express Hox genes of the first four paralogous groups. Each rhombomere (or pair of rhombomeres) is characterized by a combinatorial Hox gene expression (Hoxcode); mutational analyses carried out in the mouse have shown that Hox genes are critical for patterning these neural crest derivatives as they are for the development of the vertebral column from the paraxial mesoderm and of the brain stem from the rhombencephalon.

We are presently engaged in exciting work about the formation of the facial skeleton. A post-doctoral fellow, Sophie Creuzet, is particularly active on this project. In vivo transplantation experiments have demonstrated that Hox -positive and Hox negative domains are not equivalent in the genesis of the facial and hypobranchial skeleton, since only the latter is able to yield the facial bones (Creuzet et al., 2002). Moreover, within the Hox -negative domain including the diencephalic, mesencephalic and anterior rhombencephalic levels ( $r 1-r 2)$, the NC possesses a high regeneration capacity. For example a quarter of the endogenous NC, whatever its level of origin (e.g., diencephalic, mesencephalic 
or rhombencephalic), is able to reconstitute the entire facial and lower jaw skeleton. This means that the information encoding any particular element of the facial skeleton does not belong to the NC proper but is imposed on it by extrinsic cues. Recent work has revealed that the foregut endoderm plays a decisive role in patterning the facial skeleton (Couly et al., 2002). We are presently trying to identify the nature of these endodermal signals. On the other hand, gain of function experiments, in which Hox genes were electroporated into the Hox -negative domain of the NC, have shown that expression of these genes inhibits the differentiation of the facial cartilages and bones (Creuzet et al., 2002).

\section{The segregation of the cell lineages arising from the neural crest: the first demonstration of a «neural stem cell»}

One of the most striking features of the NC is the potential to give rise to a large number of different cell types. This being established, the next question was to try and decipher how and when these different cell lineages become segregated. The work carried out in vivo demonstrated that each level of the NC contains a range of developmental potentialities larger than those actually used during development. The role of environmental signals thus appeared essential in determining NCC fate. Along the same line, we had demonstrated that, once differentiated, the peripheral ganglia contain undifferentiated and still highly pluripotent precursors in their non-neuronal population, which, if transplanted into appropriate sites of a younger host, can be coaxed into differentiation. Thus, cells retaining the pluripotent character of NC progenitors are set aside during the development of the PNS ganglia and remain quiescent there. These results take a novel significance in the light of experiments disclosing the presence of pluripotent stem cells in the adult body. Moreover, they opened new avenues of research which required in vitro investigations on the $\mathrm{NC}$.

\section{The development of sensory neurons depends upon signals arising from spinal cord}

Our previous observations pointed to the fact that, among PNS neurons, the precursors of sensory neurons are specified before those which differentiate in the autonomic ganglia. I proposed that the development of DRG (dorsal root ganglia) neurons depends upon signals arising from the spinal cord. Chaya Kalcheim, a postdoctoral fellow from Israel, performed very demonstrative experiments which confirmed this hypothesis and showed that survival of sensory precursors depends on BDNF, a neurocytokine produced by the neural tube. Chaya Kalcheim's contribution during her post-doc was very significant. She returned to Israel where she established a now renowned laboratory where she pursues research on the neural crest and somite development. She and I co-authored a second edition of «The Neural Crest» in 1999.

\section{In vitro culture of neural crest cells}

It was clear that each derivative of the NC required different types of growth and survival factors to differentiate. These signalling

\footnotetext{
${ }^{4}$ Quail NCC were chosen because Cohen and Königsberg had shown in 1975 that they were easier to cultivate than chick NCC.
}

molecules are likely to be provided by the «milieu» in which the NCC become localized at the term of (or during) their migration. One way to analyze these interactions was to set up culture conditions in which NCC can survive and further develop.

Catherine Ziller, like me a former pupil of Etienne Wolff, took over the project and set up appropriate conditions to culture quail $\mathrm{NCC}^{4}$. Anne Baroffio, a postdoctoral fellow, together with Elisabeth Dupin developed a method that allowed clonal cultures of NCC in which, in principle, the full expression of their differentiating capabilities met no restrictions. This allowed us to show that, as early as the migratory stage, NCC form a heterogeneous population of cells with different commitments. Fully committed precursors giving clones with only one cell type were found, as well as pluripotent progenitors, in respective proportions of about $20 \%$ and $80 \%$. The putative NC stem cell able to give rise to virtually all the phenotypes derived from this structure was also found. As expected the incidence of this totipotent stem cell in the NC is low (about $0.3 \%$ in our cultures). Building on these results, we could propose a cell lineage model that accounts for the diversification of NC derivatives from a multipotent stem cell (Le Douarin et al., 2004). This first identification of a «neural stem cell» in the nervous system was confirmed by other groups in the US and followed by the demonstration of neural stem cells in the central nervous system (CNS).

This work is now pursued in our group by Elisabeth Dupin and several co-workers. Recently they showed that several pluripotent progenitors such as those able to give rise to glial, pigment and smooth muscle cells (GMF precursors) or only glial cells and melanocytes (GM precursors) are endowed with self-renewal capacities and thus can be considered as «stem cells» (Trentin et al., 2004; Le Douarin et al., 2004). It was obvious that a parallel could be established between the segregation of cell lineages in the NC and in the hematopoietic system.

This led to the search for growth and survival factors able to promote the proliferation and differentiation of a selected set of precursor cells in each type of NC derivatives. The identification of molecular markers specific for the different cell types arising from NC progenitors was a prerequisite for the analysis of the phenotypes present in the cultures. In the $1980^{\text {ies }}$ onward, my laboratory engaged in the production of monoclonal antibodies directed against molecular markers for the avian NCC and their derivatives, some of which have been studied in depth.

For example, the SMP Mab led to the cloning of the gene and the purification of the Schwann cell myelin protein which exhibits a strict specificity for oligodendrocytes in the CNS and the Schwann cells in the PNS (Dulac et al., 1988, 1992). Its expression by PNS glial cells turns out to be constitutive during the process of differentiation and to be strongly repressed by the gut environment, in the case of enteric glial cells and in the peripheral ganglia in satellite cells (Dulac and Le Douarin, 1991). SMP was discovered and studied by Catherine Dulac, now professor at Harvard University (see Tietjen et al., 2005 in this issue) and by late Patricia Cameron-Curry who sadly died of acute lymphocytic leukemia only one month after being diagnosed at the age of 35. Patricia came to our laboratory as an Italian postdoctoral fellow and decided to stay in France. She had just been appointed to an INSERM position when she suddenly fell sick. This was for us a terrible shock and a great loss.

Among the secreted factors we studied, endothelin 3 (ET3) was the most interesting. Laure Lecoin, Ronit Lahav and Valérie 
Nataf worked very successfully on this project (Lahav et al., 1996, 1998; Nataf et al., 1996, 1998a,b; Lecoin et al., 1998) and this work is presently pursued actively by Elisabeth Dupin and her coworkers (Dupin etal., 2000, 2003; Trentin etal., 2004; Le Douarin, 2004; Le Douarin et al., 2004 and Real et al., 2005 in this issue).

\section{The somites}

The somites, or segmented paraxial mesoderm, are located on each side of the axial organs, namely neural tube and notocord. They give rise to vertebrae and striated muscles of the body which develop from the so-called myotomes. The Q/C marker system was instrumental in showing that the striated muscles of the limb are not generated in the limb bud itself but originate from somitic myotomal cells which migrate into the limb bud. This was demonstrated by Madeleine Kieny in the laboratory headed by Philippe Sengel in Grenoble. Pr. Charles Ordahl, who spent a sabbatical year in Nogent, refined the analysis of the fate of myotomal cell fate and performed elegant experiments leading to the clear distinction of epaxial (dorsal) and hypaxial (ventrolateral) muscles showing that the striated muscles of the whole body originate from somitic myotomal precursors (Ordahl and Le Douarin, 1992).

Yoshiko Takahashi, a post-doctoral researcher from Japan followed by Anne-Hélène Monsoro, a graduate student, cloned the chick homologue of the Msx gene and demonstrated that the vertebral cartilage develops according to two different, mutually exclusive, genetic pathways. One depends on notocord secreted $\mathrm{SHH}$ and is responsible for the development of the vertebral body and neural arches. SHH induces the expression of PaxP in the sclerotomal mesenchyme. Closure of the neural arches and formation of the spinous processes are under a different genetic control involving the BMP4 growth factor (produced by the superficial ectoderm) and transcription factors MsX1 and MsX2 (Monsoro-Burq and Le Douarin, 2000).

Removal of notocord and neural tube abolishes vertebral formation (Teillet and Le Douarin, 1983). In contrast, graft of a supernumerary notocord laterally to the neural tube induces a secondary vertebral body (Pourquié et al, 1993).

The somites have an important role on the formation of certain NC derivatives since they define the routes of migration for NCC. These processes were finely studied by Chaya Kalcheim and Marie-Aimée Teillet (Teillet et al, 1987; Kalcheim and Teillet, 1989).

\section{Neurulation in amniotes revisited}

Neurulation was classically considered as resulting from of an induction of the ectoderm by the «organizer» and its derivative, the notocord. The resulting neural plate was thought to be a homogeneous sheet of epithelial cells in which the notocord was supposed to introduce heterogeneity secondarily by inducing the neuroepithelial cells to become the floor plate, a medial structure playing an important role in neural tube patterning.

The accepted view was that a protein, encoded by the gene sonic hedgehog (shh) and secreted by the notocord, induced the floor plate. According to this view, the induced floor plate produces a transcription factor of the forkhead family, HNF3 $\beta$, which in turn is supposed to control the production of $\mathrm{SHH}$ protein by floor plate cells. $\mathrm{SHH}$ is further considered as in important molecule for specifying the various types of neurons that differentiate in the spinal cord. Using the Q/C marker system in ovo, we traced the fate of the avian organizer (Hensen's node cells) throughout ontogeny. It turned out that the cells of the organizer which express HNF3 $\beta$ from the onset of gastrulation yield not only the notocord, as previously thought, but also the floor plate and a strip of cells in the dorsal endoderm. During gastrulation and neurulation, Hensen's node moves along the anteroposterior axis according to a process called «regression», leaving in its wake these three mediodorsal structures.

Pr. De Robertis, who was spending some time in the laboratory upon our invitation to lecture at the Collège de France, participated in this work (Catala et al., 1996). This experiment and others thus challenged the role of the notocord in floor plate induction during normal development. In fact, the floor plate develops in a cell autonomous manner and the notocord is not required for patterning the nervous system. Those observations are supported by several genetic data particularly by the existence of mutants in zebrafish (e.g., floating head) in which a floor plate develops in a normally patterned neural tube in the total absence of a notocord.

Our results therefore lead to reconsider the classical notions about the process of gastrulation and neurulation in the vertebrate phylum. They have also disclosed a novel role for the protein $\mathrm{SHH}$ during neurulation. If the development of the notocord and floor plate is prevented by extirpating Hensen's node, the neural tube (devoid of a floor plate) and the paraxial mesoderm form in the absence of these axial structures, but they become rapidly the target of massive cell death. Thus, one of the primary roles of these midline structures in the vertebrate embryo is to prevent the neural and mesodermal cells from triggering their cell death programme.

This work, carried out by Martin Catala, Jean-Baptiste Charrier and Marie-Aimée Teillet (Charrier et al., 2005 in this issue), is continuing in collaboration with the group of Dr. Patrick Mehlen and especially concerns the antiapoptotic role of $\mathrm{SHH}$ during development (Thibert et al., 2003).

\section{The hemangioblast}

In line with my former interest in hematopoiesis, my laboratory has recently contributed to substantiating a long standing concept, that of the hemangioblast.

Our early work on hemopoietic stem cells, carried out by Bruno Péault with the skillfull technical help of Monique Coltey, has attracted our attention to the close relationships between endothelial and blood cells in the yolk sac blood islands. This was made possible by using the MB1-Mab, produced by Bruno, which was the first of the numerous species- and cell type-specific antibodies that we further prepared to analyze the chimeras.

The idea had been proposed in the first decades of the $X X^{\text {th }}$ century, by Vera Dantchakoff and later on by Florence Sabin and P.D.F. Murray, that both the endothelial and hemopoietic lineages are derived from a common precursor, «the hemangioblast». The existence of such a cell during development had not been demonstrated. Anne Eichmann, a graduate student, started her thesis work by searching tyrosine-kinase receptor genes transcribed during early embryogenesis. Among 23 cDNAs, two were transcribed exclusively in the endothelial cells of blood 
vessels. None of the two sequences had been previously described and the possibility was high that they might encode two receptors for putative vascular endothelial growth factors. The existence of specific growth factors for vascular endothelial cells was very likely, although none had so far been evidenced. Anne cloned these two genes and called them Quek1 and Quek2 (because they were cloned from the quail). She obtained their protein products and the corresponding Mabs. Some months later, similar molecules were found in mammals, confirming our hypothesis, when the ligand «vascular endothelial growth factor» (VEGF) was discovered. From that time on, the receptors were designated as VEGFR2 and VEGFR3 (for Quek1 and Quek2 respectively).

We found that VEGFR2 is expressed very early in the mesoderm during gastrulation. With the anti-VEGFR2 Mab we were able to sort out by FACS the mesodermal cells expressing this antigen. The VEGFR2 ${ }^{+}$cells, cultured clonally without VEGF, differentiated into hemopoietic cells (Eichmann et al., 1997). If VEGF was added to the medium the cells were induced to differentiate into endothelial cells. Thus, mesodermal cells destined to form the yolk sac blood islands carrying the same VEGFR2 marker were able, according to the environment they were subjected to in vitro, to differentiate into either blood cells or endothelial cells (Eichmann etal., 1997). This property designated them as the hemangioblast, an interpretation supported by the fact that mice with a VEGFR2 gene knock-out die early in embryogenesis and lack both blood and endothelial cells (Shalaby et al., 1995).

\section{Concluding remarks}

This story covers more than forty years of my life in Science. The Nogent Institute devoted its activity to the study of embryological problems and did so essentially on one single model, the avian embryo.

I received recently a special issue of the journal «Mechanisms of Development», entitled «The Chick in Developmental Biology», initiated by Claudio Stern, the co-ordinating Editor (Stern, 2004). A draft sequence covering the entire chicken genome has now been generated by Washington University (Saint-Louis). The chick, as a model system for biology, is entering the genomic world, thus rejoining Drosophila, zebrafish and nematode.

Another satisfaction is that an important new asset for the chick has come from the technique developed by Harukasu Nakamura, a former post-doctoral fellow in Nogent. This technique allows time/space controlled gain- or loss-of-function genetic manipulations in the embryo in ovo.

I wish to say, in fine, that this 40 -year venture with the avian embryo has been a permanent intellectual excitement for me; so intense and passionate that I cannot believe that it should ever end.

I am grateful to all those who have shared this research with me. I particularly wish to acknowledge the long standing collaboration that I enjoyed over so many years with my colleague Marie-Aimée Teillet. Her skills and talent in performing, interpreting and devising the $\mathrm{Q} / \mathrm{C}$ experiments are exceptional and it has been my great satisfaction to interact with her on the diverse projects that we have undertaken and completed together. It has been, in all respects, a great pleasure to work with Marie-Aimée.

A very special thought goes to one of my first students, Christiane Ayer-Le Lièvre, who became a distinguished scientist and to Patrizia Cameron-Curry. Both passed away, we remember them fondly and deeply regret their departure.

\section{Summary}

The Nogent Institute, founded by Etienne Wolff in 1955, was dedicated to the study of the avian model. The quail-chick chimera marking system, devised in 1969, gave a new impetus to the analysis of cell migrations and interactions in the developing nervous, immune and hematopoietic systems. These studies, still very active, have been extended by various groups the world over.

KEY WORDS: quail-chick chimera, neural crest, central nervous system, immune tolerance, hemangioblast

\section{References}

AYER-LE LIÈVRE, C. S. and LE DOUARIN, N. M. (1982). The early development of cranial sensory ganglia and the potentialities of their component cells studied in quail-chick chimeras. Dev. Biol. 94:291-310.

BALABAN, E., TEILLET, M. A. and LE DOUARIN, N. (1988). Application of the quail-chick chimera system to the study of brain development and behavior. Science 241: 1339-1342.

BALABAN, E. (2005). Brain switching: studying evolutionary behavioral changes in the context of individual brain development. Int. J. Dev. Biol. 49: 117-124. doi: 10.1387/ijdb.041934eb.

BATINI, C., TEILLET, M. A., NAQUET, R. and LE DOUARIN, N. M. (1996). Brain chimeras in birds: application to the study of a genetic form of reflex epilepsy. Trends Neurosci. 19: 246-252.

BELO, M., MARTIN, C., CORBEL, C. and LE DOUARIN, N. M. (1985). A novel method to bursectomize avian embryos and obtain quail/chick bursal chimeras. I. Immunocytochemical analysis of such chimeras by using species-specific monoclonal antibodies. J. Immunol. 135: 3785-3794.

BELO, M., CORBEL, C., MARTIN, C. and LE DOUARIN, N. M. (1989). Thymic epithelium tolerizes chickens to embryonic graft of quail bursa of Fabricius. Int. Immunol. 1: 105-112.

BURNS, A. J. and LE DOUARIN, N. M. (1998). The sacral neural crest contributes neurons and glia to the post-umbilical gut: spatiotemporal analysis of the development of the enteric nervous system. Development 125: 4335-4347.

BURNS, A. J. and LE DOUARIN, N. M. (2001). Enteric nervous system development: analysis of the selective developmental potentialities of vagal and sacral neural crest cells using quail-chick chimeras. Anat Rec. 262: 16-28.

BILLINGHAM, R. E., BRENT, L. and MEDAWAR, P. B. (1953). Actively acquired tolerance of foreign cells. Nature 172: 603-606

CATAlA, M., TEILLET, M. A., DE ROBERTIS, E. M. and LE DOUARIN, N.M. (1996). A spinal cord fate map in the avian embryo: while regressing, Hensen's node lays down the notocord and floor plate thus joining the spinal cord lateral walls. Development. 122: 2599-2610.

CHARRIER, J.-B., CATALA, M., LE DOUARIN, N. and TEILLET, M.A. (2005). Cellular dynamics and molecular control of the development of organizerderived cells studied in quail-chick chimeras. Int. J. Dev. Biol. 49: 181-191. doi 10.1387/ijdb.041962jc

COHEN, A. M. and KÖNIGSBERG, I. R. (1975). A clonal approach to the problem of neural crest determination. Dev. Biol. 46: 262-280.

CORBEL, C., BELO, M., MARTIN, C. and LE DOUARIN, N. M. (1987). A novel method to bursectomize avian embryos and obtain quail/chick bursal chimeras. II. Immune response of bursectomized chicks and chimeras and post-natal rejection of the grafted quail bursas. J. Immunol. 138: 2813-2821.

CORBEl, C., MARTIN, C., OHKI, H., COltey, M., HLOZANEK, I. and LE DOUARIN, N. M. (1990). Evidence for peripheral mechanisms inducing tissue tolerance during ontogeny. Int Immunol. 2: 33-40.

COULY, G. F. and LE DOUARIN, N. M. (1987). Mapping of the early neural primordium in quail-chick chimeras. II. The prosencephalic neural plate and 
neural folds: implications for the genesis of cephalic human congenital abnormalities. Dev. Biol. 120: 198-214.

COULY, G. F., COLTEY, P. M. and LE DOUARIN, N. M. (1993). The triple origin of skull in higher vertebrates: a study in quail-chick chimeras. Development 117: 409-429.

COULY, G., CREUZET, S., BENNACEUR, S., VINCENT, C. and LE DOUARIN, N M. (2002). Interactions between Hox-negative cephalic neural crest cells and the foregut endoderm in patterning the facial skeleton in the vertebrate head. Development 129: 1061-1073.

COUTHINO, A. (2005). The Le Douarin phenomenon; a shift in the paradigm of developmental self-tolerance. Int. J. Dev. Biol. 49: 131-136. doi: 10.1387/ ijdb.041965ac.

CREUZET, S., COULY, G., VINCENT, C. and LE DOUARIN, N. M. (2002). Negative effect of Hox gene expression on the development of the neural crest-derived facial skeleton. Development 129: 4301-4013.

CROSSLEY, P. H., MARTINEZ, S. and MARTIN, G. R. (1996). Midbrain development induced by FGF8 in the chick embryo. Nature 380: 66-68.

DHOUAILLY, D., OLIVERA-MARTINEZ, I, FLINIAUX, I., MISSIER, S., VIALLET, J.P. and THELU, J.. (2004). Skin field formation: morphogenetic events. Int. J. Dev. Biol. 48: 85-91.

DIETERLEN-LIĖVRE, F. (1990). Sex, differentiation and cancer. An interview with Prof. Etienne Wolff, pioneer researcher and promoter of modern developmental biology in France. Int. J. Dev. Biol. 34: 5-9.

DIETERLEN-LIÈVRE, F. (2005). Commitment of hematopoietic stem cells in avian and mammalian embryos: an ongoing story. Int. J. Dev. Biol. 49: 125-130. doi: $10.1387 / \mathrm{ijdb} .041938 \mathrm{fd}$

DULAC, C. and LE DOUARIN, N. M. (1991). Phenotypic plasticity of Schwann cells and enteric glial cells in response to the microenvironment. Proc. Natl. Acad. Sci. USA 88: 6358-6362.

DULAC, C., CAMERON-CURRY, P., ZILLER, C. and LE DOUARIN, N. M. (1988). A surface protein expressed by avian myelinating and nonmyelinating Schwann cells but not by satellite or enteric glial cells. Neuron 1:211-220.

DULAC, C., TROPAK, M. B., CAMERON-CURRY, P., ROSSIER, J., MARSHAK, D. R., RODER, J. and LE DOUARIN, N. M. (1992). Molecular characterization of the Schwann cell myelin protein, SMP: structural similarities within the immunoglobulin superfamily. Neuron 8: 323-334.

DUPIN, E., GLAVIEUX, C., VAIGOT, P. and LE DOUARIN, N. M. (2000). Endothelin 3 induces the reversion of melanocytes to glia through a neural crest-derived glial-melanocytic progenitor. Proc. Natl. Acad. Sci. USA 97: 7882-7887.

DUPIN, E., REAL, C., GLAVIEUX-PARDANAUD, C., VAIGOT, P. and LE DOUARIN, N. M. (2003). Reversal of developmental restrictions in neural crest lineages: transition from Schwann cells to glial-melanocytic precursors in vitro. Proc. Nat/. Acad. Sci. USA 100: 5229-5233.

EICHMANN, A., CORBEL, C., NATAF, V., VAIGOT, P., BREANT, C. and LE DOUARIN, N. M. (1997). Ligand-dependent development of the endothelial and hemopoietic lineages from embryonic mesodermal cells expressing vascular endothelial growth factor receptor 2. Proc. Natl. Acad. Sci. USA 94: 5141-5146.

ETCHEVERS, H. C., VINCENT, C., LE DOUARIN, N. M. and COULY, G. F. (2001). The cephalic neural crest provides pericytes and smooth muscle cells to all blood vessels of the face and forebrain. Development 128:1059-1068.

FEHILLY, C. B., WILLADSEN, S. M. and TUCKER, E. M. (1984). Interspecific chimaerism between sheep and goat. Nature 307: 634-636.

FLINIAUX, I., VIALLET, J.P. and DHOUAILLY, D. (2004). Ventral vs. dorsal chick dermal progenitor specification. Int. J. Dev. Biol. 48: 103-106.

FONTAINE-PÉRUS, J. C., CHANCONIE, M., LE DOUARIN, N. M., GERSHON, M. D. and ROTHMAN, T.P. (1989). Mitogenic effect of muscle on the neuroepithelium of the developing spinal cord. Development 107: 413-422.

GANS, C. and NORTHCUTT, R. G. (1983). Neural crest and the origin of vertebrates. A new head. Science. 220: 268-274.

GRAPIN-BOTTON, A., BONNIN, M. A., MCNAUGHTON, L. A., KRUMLAUF, R. and LE DOUARIN, N. M. (1995). Plasticity of transposed rhombomeres: Hox gene induction is correlated with phenotypic modifications. Development 121: 2707-2721.

GRAPIN-BOTTON, A. (2005). Antero-posterior patterning of the vertebrate digestive tract. 40 years after Nicole Le Douarin's PhD thesis. Int. J. Dev. Biol. 49: 335347. doi: 10.1387/ijdb.041946ag
GUILLEMOT, F. P., OLIVER, P. D., PÉAULT, B. M. and LE DOUARIN, N. M. (1984). Cells expressing la antigens in the avian thymus. J. Exp. Med.160:1803-1819.

HALlONET, M. E., TEILlet, M. A. and LE DOUARIN, N. M. (1990). A new approach to the development of the cerebellum provided by the quail-chick marker system. Development 108: 19-31.

HAMBURGER, V. (1961). Experimental analysis of the dual origin of the trigeminal ganglion in the chick embryo. J. Exp. Zool. 148: 91-123.

HÖRSTADIUS, S. (1950). The neural crest: its properties and derivatives in the light of experimental research. London, Oxford University Press.

HOUSSAINT, E., BELO, M. and LE DOUARIN, N. M. (1976). Investigations on cell lineage and tissue interactions in the developing bursa of Fabricius through interspecific chimeras. Dev. Biol. 53:250-264.

JOHNSTON, M. C. (1966). A radioautographic study of the migration and fate of cranial neural crest cells in the chick embryo. Anat. Rec. 156: 143-156.

JOTEREAU, F. V. and LE DOUARIN, N. M. (1982). Demonstration of a cyclic renewal of the lymphocyte precursor cells in the quail thymus during embryonic and perinatal life. J. Immunol. 129:1869-1877.

KALCHEIM, C. and TEILLET, M. A. (1989). Consequences of somite manipulation on the pattern of dorsal root ganglion development. Development. 106: 85-93.

KINUTANI, M., COLTEY, M. and LE DOUARIN, N. M. (1986). Postnatal development of a demyelinating disease in avian spinal cord chimeras. Cel/ 45:307-314.

KIRBY, M. L., TURNAGE, K. L. and HAYES, B. M. (1985). Characterization of conotruncal malformations following ablation of «cardiac» neural crest. Anat. Rec. 213:87-93.

KIRRMANN, J. M. (1962) Expériences de radioprotection et de radiosensibilisation sur des organes embryonnaires du poulet. Bull. Biol. Fr. Belg. 96: 365-463.

LAHAV, R., ZILLER, C., DUPIN, E. and LE DOUARIN, N. M. (1996). Endothelin 3 promotes neural crest cell proliferation and mediates a vast increase in melanocyte number in culture. Proc. Natl. Acad. Sci. USA 93: 3892-3897.

LAHAV, R., DUPIN, E., LECOIN, L., GLAVIEUX, C., CHAMPEVAL, D., ZILLER, C. and LE DOUARIN, N. M. (1998). Endothelin 3 selectively promotes survival and proliferation of neural crest-derived glial and melanocytic precursors in vitro. Proc. Natl. Acad. Sci. USA 95: 14214-14219.

LE DOUARIN, G. (1964). Etude de l'action des rayons X sur la physiologie et l'organogenèse du coeur embryonnaire chez le Poulet. Bull. Biol. Fr. Belg. 97 : 643-759.

LE DOUARIN, N. (1964a). Induction de l'endoderme pré-hépatique par le mésoderme de l'aire cardiaque chez l'embryon de Poulet. J. Embryol. Exp. Morph. 12:651676.

LE DOUARIN, N. (1964b). Isolement expérimental du mésenchyme propre du foie et rôle morphogène de la composante mésodermique dans l'organogenèse hépatique. J. Embryol. Exp. Morphol. 12:141-160.

LE DOUARIN, N. (1964c). Etude expérimentale de l'organogenèse du tube digestif et du foie chez l'embryon de Poulet. Bull. Biol. Fr. Belg. 98:544-674.

LE DOUARIN, N. (1966). L'hématopoïèse dans les formes embryonnaires et jeunes des Vertébrés. Ann. Biol. 5: 105-171.

LE DOUARIN, N. M. (1973). A Feulgen-positive nucleolus. Exp. Cell Res. 77:459468.

LE DOUARIN, N. M. (1976). Ontogeny of primary lymphoid organs. In $B$ and T cells in immune recognition (eds F. Loor and G. E. Roelants), Ch. 1, pp. 1-19. New York, John Wiley and sons Inc.

LE DOUARIN, N. M. (1977). Thymus ontogeny studied in interspecific chimeras. In Development of Host Defenses (eds M. D. Cooper and D. H. Dayton), pp. 1127. New York, Raven Press.

LE DOUARIN, N. M. (1980). The ontogeny of the neural crest in avian embryo chimaeras. Nature. 286: 663-669.

LE DOUARIN, N. (1982). The Neural Crest. Cambridge, Cambridge University Press.

LE DOUARIN, N.M. (2004). The avian embryo as a model to study the development of the neural crest: a long and still ongoing story. Mech. Dev. 121: 1089-1102.

LE DOUARIN, N. M. and JOTEREAU, F. (1973). Origin and renewal of lymphocytes in avian embryo thymuses through embryonic life in interspecific chimeras. Nature New Biol. 246: 25-27. 
LE DOUARIN, N. M. and JOTEREAU, F. V. (1975). Tracing of cells of the avian thymus through embryonic life in interspecific chimeras. J. Exp. Med. 142:17-40.

LE DOUARIN, N. M. and KALCHEIM, C. (1999). The Neural Crest (second edition). New York: Cambridge University Press.

LE DOUARIN, N. and LE LIÈVRE, C. (1970). Démonstration de l'origine neurale des cellules à calcitonine du corps ultimobranchial chez l'embryon de Poulet. C.R. Acad. Sci. Paris 270, 2857-2860.

LE DOUARIN, N. and LE LIÈVRE, C. (1971). Sur l'origine des cellules à calcitonine du corps ultimobranchial de l'embryon d'Oiseau. Bull. Assoc. Anat. 152: 558-568.

LE DOUARIN, N. and LE LIÈVRE, C. (1972). Demonstration of the neural origin of the ultimobranchial body glandular cells in the avian embryo. International Symposium of Endocrinology, July 1971, London.

LE DOUARIN, N. M. and TEILLET, M. A. (1973). The migration of neural crest cells to the wall of the digestive tract in avian embryo. J. Embryol. Exp. Morphol. $30: 31-48$.

LE DOUARIN, N. M. and TEILLET, M.-A. (1974). Experimental analysis of the migration and differentiation of neuroblasts of the autonomic nervous system and of neurectodermal mesenchymal derivatives, using a biological cell marking technique. Dev. Biol. 41:162-184.

LE DOUARIN, N., BUSSONET, C. and CHAUMONT, F. (1968). Etude des capacités de différenciation et du rôle morphogène de l'endoderme pharyngien chez l'embryon d'Oiseau. Ann. Embryol. Morphog. 1: 29-39.

LE DOUARIN, N., LE LIÈVRE, C. and FONTAINE, J. (1972). Recherches expérimentales sur l'origine embryologique du corps carotidien chez les Oiseaux. C. R. Acad. Sci., Série III, Paris. 275:583-586.

LE DOUARIN, N., FONTAINE, J. and LE LIĖVRE, C. (1974). New studies on the neural crest origin of the avian ultimobranchial glandular cells. Interspecific combinations and cytochemical characterization of $\mathrm{C}$ cells based on the uptake of biogenic amine precursors. Histochemistry 38:297-305.

LE DOUARIN, N. M., RENAUD, D., TEILLET, M.-A. and LE DOUARIN, G. H. (1975a). Cholinergic differentiation of presumptive adrenergic neuroblasts in interspecific chimeras after heterotopic transplantations. Proc. Natl. Acad. Scl. USA 72:728-732.

LE DOUARIN, N. M., HOUSSAINT, E., JOTEREAU, F. V. and BELO, M. (1975b). Origin of hemopoietic stem cells in embryonic bursa of Fabricius and bone marrow studied through interspecific chimeras. Proc. Natl. Acad. Sci. USA72: 2701-2705.

LE DOUARIN, N.M., JOTEREAU, F.V. and HOUSSAINT, E. (1976a). The lymphoid stem cells in the avian embryo. In Phylogeny of Thymus and Bone Marrow Bursa Cells. (Eds R.K. Wright and E.L. Cooper) pp. 217-226. Amsterdam, Elsevier/North Holland Biomedical Press.

LE DOUARIN, N. M., JOTEREAU, F. V., HOUSSAINT, E. and BELO, M. (1976b). Ontogeny of the avian thymus and bursa of Fabricius studied in interspecific chimeras. Ann. Immunol. 127:849-856.

LE DOUARIN, N.M., HOUSSAINT E. and JOTEREAU F. (1977). Differentiation of the primary lymphoid organs in avian embryos: origin and homing of the lymphoid stem cells. In Avian Immunology, (ed. A.A. Benedict), New York, Plenum Publishing Corporation, pp. 29-37.

LE DOUARIN, N.M., SMITH, J.,TEILLET, M.-A., LE LIĖVRE, C.S. and ZILLER, C. (1980). The neural crest and its developmental analysis in avian embryo chimeras. Trends Neurosci. 3: 39-42.

LE DOUARIN, N. M., CORBEL, C., MARTIN, C., COLTEY, M. and SALAÜN, J. (1989). Induction of tolerance by embryonic thymic epithelial grafts in birds and mammals. Cold. Spring. Harbor Symp. Quant. Biol. 54: 777-787.

LE DOUARIN, N., CORBEL, C., BANDEIRA, A., THOMAS-VASLIN, V., MODIGLIANI, Y., COUTINHO, A. and SALAÜN, J. (1996). Evidence for a thymus-dependent form of tolerance that is not based on elimination or anergy of reactive T cells. Immunol. Rev. 149: 35-53.

LE DOUARIN, N.M., CREUZET, S., COULY, G. and DUPIN, E. (2004). Neural crest cell plasticity and its limits. Development 131: 4637-4650.

LE LIÈVRE, C. (1974). Rôle des cellules mésectodermiques issues des crêtes neurales céphaliques dans la formation des arcs branchiaux et du squelette viscéral. J. Embryol. Exp. Morph. 31: 453-477.

LECOIN, L., SAKURAI, T., NGO, M. T., ABE, Y., YANAGISAWA, M. and LE DOUARIN, N. M. (1998). Cloning and characterization of a novel endothelin receptor subtype in the avian class. Proc. Natl. Acad. Sci. USA 95: 3024-3029.
MONSORO-BURQ, A. H. and LE DOUARIN, N. (2000). Duality of molecular signaling involved in vertebral chondrogenesis. Curr. Top. Dev. Biol. 48: 43-75.

NATAF, V., LECOIN, L., EICHMANN, A. and LE DOUARIN, N. M. (1996). Endothelin$B$ receptor is expressed by neural crest cells in the avian embryo. Proc. Natl. Acad. Sci. USA 93: 9645-9650.

NATAF, V., AMEMIYA, A., YANAGISAWA, M. and LE DOUARIN, N. M. (1998a). The expression pattern of endothelin 3 in the avian embryo. Mech. Dev. 73: 217-220.

NATAF, V., GRAPIN-BOTTON, A., CHAMPEVAL, D., AMEMIYA, A., YANAGISAWA M. and LE DOUARIN, N. M. (1998b). The expression patterns of endothelin-A receptor and endothelin 1 in the avian embryo. Mech. Dev. 75: 145-149.

OHKI, H., MARTIN, C., CORBEL, C., COLTEY, M. and LE DOUARIN, N. M. (1987). Tolerance induced by thymic epithelial grafts in birds. Science 237: 1032-1035.

OLIVER, P.D. and LE DOUARIN, N.M. (1984). Avian thymic accessory cells. $J$. Immunol., 132: 1748-1755.

OLIVERA-MARTINEZ, I., THELU, J. AND DHOUAILLY, D. (2004). Molecular mechanisms controlling dorsal dermis generation from the somitic dermomyotome. Int. J. Dev. Biol. 48: 93-101.

ORDAHL, C. P. and LE DOUARIN, N. M. (1992). Two myogenic lineages within the developing somite. Development 114: 339-353.

PATTERSON, P. H. and CHUN, L. L. (1977). The induction of acetylcholine synthesis in primary cultures of dissociated rat sympathetic neurons. I. Effects of conditioned medium. Dev. Biol. 56: 263-280.

PEARSE, A. G., POLAK, J. M., ROST, F. W., FONTAINE, J., LE LIÈVRE, C. and LE DOUARIN, N. (1973). Demonstration of the neural crest origin of type I (APUD) cells in the avian carotid body, using a cytochemical marker system. Histochemie 34: 191-203.

POLAK, J. M., PEARSE, A. G., LE LIÈVRE, C., FONTAINE, J. and LE DOUARIN, N. M. (1974). Immunocytochemical confirmation of the neural crest origin of avian calcitonin-producing cells. Histochemistry 40: 209-214.

POURQUIÉ, O., COLTEY, M., TEILLET, M. A., ORDAHL, C. and LE DOUARIN, N. M. (1993). Control of dorsoventral patterning of somitic derivatives by notocord and floor plate. Proc. Natl. Acad. Sci. USA 90: 5242-5246.

REAL, C., GLAVIEUX-PARDANAUD, C., VAIGOT, P., LE DOUARIN, N.M. and DUPIN, E. (2005). The instability of the neural crest phenotypes: Schwann cells can differentiate into myofibroblasts Int. J. Dev. Biol. 49: 151-159. doi: 10.1387/ ijdb.041940cr

SAKAGUCHI, S., TAKAHASHI, T. and NISHIZUKA, Y. (1982). Study on cellular events in post thymectomy autoimmune oophoritis in mice. I. Requirement of Lyt1 effector cells for oocytes damage after adoptive transfer. J. Exp. Med. 156:15651576.

SALAÜN, J., CALMAN, F., COLTEY, M. and LE DOUARIN, N. M. (1986). Construction of chimeric thymuses in the mouse fetus by in utero surgery. Eur. J. Immunol. 16 523-530.

SALAÜN, J., CORBEL, C. and LE DOUARIN, N.M. (2005). Regulatory T cells in the establishment and maintenance of self-tolerance: role of the thymic epithelium. Int J. Dev. Biol. 49: 137-142. doi: 10.1387/ijdb.041959js.

SCHWEIZER, G., AYER-LE LIÈVRE, C. and LE DOUARIN, N. M. (1983). Restrictions of developmental capacities in the dorsal root ganglia during the course of development. Cel/ Diff. 13: 191-200.

SENGEL, P. (1976). Morphogenesis of skin. Cambridge, Cambridge University Press.

SHALABY, F., ROSSANT, J., YAMAGUCHI, T. P., GERTSENSTEIN, M., WU, X. F., BREITMAN, M. L. and SCHUH, A. C. (1995). Failure of blood-island formation and vasculogenesis in Flk-1-deficient mice. Nature 376: 62-66.

SMITH, J., COCHARD, P. and LE DOUARIN, N.M. (1977). Development of choline acetyltransferase and cholinesterase activities in enteric ganglia derived from presumptive adrenergic and cholinergic levels of the neural crest. Cell. Diff. 6 : 199-216

SMITH, J., FAUQUET, M., ZILLER, C. and LE DOUARIN, N.M. (1979). Acetylcholine synthesis by mesencephalic neural crest cells in the process of migration in vivo. Nature 282: 853-855

STERN, C. (2004). The Chick in Developmental Biology. Int. J. Dev. Biol., 121 (Special Issue 9)

TEILLET, M. A. and LE DOUARIN, N. M. (1983). Consequences of neural tube and notocord excision on the development of the peripheral nervous system in the chick embryo. Dev. Biol. 98: 192-211. 
TEILLET, M. A., KALCHEIM, C. and LE DOUARIN, N. M. (1987). Formation of the dorsal root ganglia in the avian embryo: segmental origin and migratory behavior of neural crest progenitor cells. Dev. Biol. 120: 329-347.

TEILLET, M.A., NAQUET, R. and BATINI, C. (2005). Transfer of an avian genetic reflex epilepsy by embryonic brain graft: a tissue autonomous process? Int. J. Dev. Biol. 49: 237-241. doi: 10.1387/ijdb.041961mt

THIBERT, C., TEILLET, M. A., LAPOINTE, F., MAZELIN, L., LE DOUARIN, N. M. and MEHLEN, P. (2003). Inhibition of neuroepithelial patched-induced apoptosis by sonic hedgehog. Science 301: 843-846.

TIETJEN, I., RIHEL, J. and DULAC, C.G. (2005). Single cell transcriptional profiles and spatial patterning of the mammalian olfactory epithelium. Int. J. Dev. Biol. 49: 201-207. doi: 10.1387/ijdb.041939it

TRENTIN, A., GLAVIEUX-PARDANAUD, C., LE DOUARIN, N. M. and DUPIN, E. (2004). Self-renewal capacity is a widespread property of various types of neural crest precursor cells. Proc. Natl. Acad. Sci. USA 101: 4495-4500.
WALSH, C. and CEPKO, C. L. (1988). Clonally related cortical cells show several migration patterns. Science 241: 1342-1345.

WESTON, J. A. (1963). A radioautographic analysis of the migration and localization of trunk neural crest in the chick. Dev. Biol. 6:279-310.

WOLFF, E. (1936a). Les bases de la tératogenèse expérimentale des Vertébrés Amniotes d'après les résultats de méthodes directes. Arch. Anat. Histol. Embryol. 22:1-382.

WOLFF, E. (1936b). L'évolution après l'éclosion des Poulets mâles transformés en intersexués par l'hormone femelle injectée aux jeunes embryons. Arch. Anat. Histol. Embryol. 223:1-28.

ZILLER, C., SMITH, J., FAUQUET, M. and LE DOUARIN, N.M. (1979). Environmentally directed nerve cell differentiation: in vivo and in vitro studies. In Development and ChemicalSpecificity of Neurons, Progress in Brain Research, Vol. 51, (eds M. Cuénod, G.W. Kreutzberg and F.E. Bloom) Amsterdam, Elsevier/North Holland Biomedical Press, pp. 59-74. 